\title{
Article
}

\section{Grace Notes: A Case for Making Mitigation the Heart of Noncapital Sentencing}

\section{Miriam S. Gohara*}

Investigation and presentation of comprehensive life history mitigation is at the heart of successful capital litigation that has contributed to a steady decline in capital sentences. Noncapital incarceration rates have also begun to level, and various legal developments have signaled a reascent of more individualized noncapital sentencing proceedings. This return to individualized sentencing invites consideration of whether life history mitigation may, as it has in capital cases, hasten a turn away from mostly retributive punishment resulting in disproportionately harsh noncapital sentencing to a more merciful rehabilitative approach. The robust capital mitigation practice required by today's prevailing professional capital defense norms developed following the Supreme Court's Eighth Amendment doctrine requiring individualized capital sentences that account for the unique characteristics of the offender. No such doctrinal imperative applies to noncapital sentencing. As a result, professional noncapital defense sentencing standards, while providing a general basis for various aspects of sentencing advocacy, remain relatively underdeveloped, though the same bases for ameliorating punishment in capital cases should apply with equal practical force to noncapital cases.

At the same time, institutional and doctrinal barriers-including high caseloads and lack of resources, the prevalence of plea bargaining, and the Supreme Court's "death is different" precedent-present formidable challenges to routine presentation of life history mitigation in noncapital cases. Therefore, the regular presentation of life history mitigation, lacking a constitutional mandate and operating in a structure different from that of capital sentencing, will depend in the immediate term on the initiative of criminal defense lawyers with the will to consistently present it in noncapital cases. A more widespread adoption of comprehensive noncapital mitigation practice will benefit individual clients, change the expectations of sentencing courts concerning what information they should have available before ordering punishment, and provide insight into the social causes of various types of crimes. Over time, as it has in capital 
cases, familiarity with the mitigating force of social history may serve as a powerful basis for empathy and amelioration of overly punitive noncapital punishment.

Table of Contents

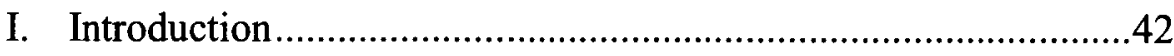

II. Context, Implications, and Overview .........................................45

III. The Development of Mitigation as the Crux of Capital Sentencing.....

A. A Brief Review of Foundational Supreme Court Eighth

Amendment Precedent in Capital Cases

B. A Brief Review of Supreme Court Sixth Amendment Precedent in Capital Cases.

C. Development of Mitigation as Standard Capital Defense Practice ........54

IV. Professional Standards of Noncapital Mitigation .......................57

A. Supreme Court Dicta on Individualized Noncapital Sentencing …........57

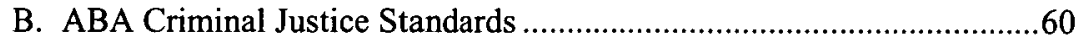

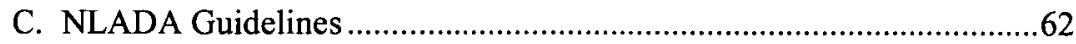

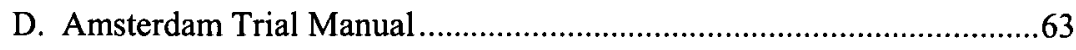

E. Implications of Noncapital Sentencing Professional Practice

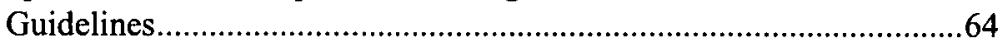

F. The Relevance of Mitigating Factors To Noncapital Sentencing ..........65

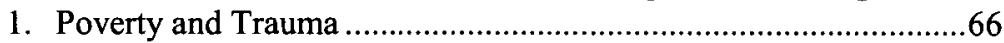

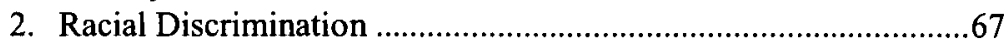

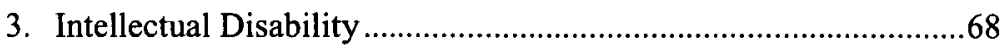

4. Positive Sentencing Factors ...........................................................69

V. Institutional Hurdles to More Robust Noncapital Mitigation .......70

A. Variety and Volume of Noncapital Cases............................................70

B. Prevalence of Plea Bargaining ............................................................74

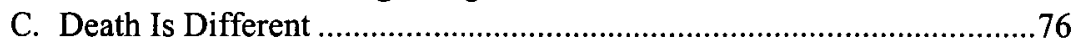

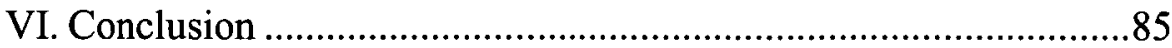

\section{Introduction}

In a New York Times interview of photographer Dawoud Bey on the occasion of a retrospective exhibit of his series of 1970s portraits of people living in Harlem, Bey described the events surrounding the taking of one of his early portraits - the first one he felt was successful. Bey had walked by a gentleman wearing an overcoat and a bowler hat and decided he wanted to take the man's picture. The man agreed, and Bey asked him to do what he had been doing before Bey interrupted him. Bey wanted his portraits to capture "natural" scenes of "people living their lives." The man then 
leaned against the railing of the brick house in front of which he had been standing and "cupped his left hand, providing what Bey calls a 'grace note."' Bey went on to explain that although he had figured out some of the technical aspects of artistic photography, "I needed the quirky little gestures of behavior that mark the individual, the stuff you can't make up. I needed a way to create a momentary connection that would leave viewers feeling they knew this person." 3

The "grace note" that Bey described is akin to the sentencing grail that lawyers representing capital defendants have a duty to discover and present to those who decide whether their clients live or die. ${ }^{4}$ It is the peculiarity ${ }^{5}$ that individualizes clients and forces a closer look at their humanity in all its complexity, including the "diverse frailties of humankind" that the Supreme Court has long recognized as central to a capital sentencer's consideration of a defendant's moral culpability. ${ }^{6}$ Unlike a static snapshot of a single moment in time, capital defense lawyers' work requires discovery and detailed presentation of life historyincluding the social, medical, economic, and historical dynamics that shape every person's behavior. In sentencing, the grace note requires a deeper moral and less fleeting engagement with the person, a beholding that calls forth empathy, mercy, and redemption, more than the momentary connection Bey inspired in his photograph.

The grace notes that capital defense lawyers have presented as characterizing their clients' backgrounds have in innumerable cases spared

Spring 2013; J.D., Harvard Law School, 1997; B.A., Columbia University, 1994. Many thanks to the following colleagues for their insightful comments and feedback on this project: Brett Dignam, Ariela Dubler, James Forman, Heather Gerken, Olati Johnson, Marcus McFerren, Tracey Meares, Linda Meyer, Ronald Resetarits, Daniel Richman, Sarah Russell, Carol Steiker, and Russell Stetler. Thanks also to participants in the University of Texas Law School's Symposium on Mass Incarceration and the Death Penalty (March 2013), to the editors of the American Journal of Criminal Law, and to Andrea McChristian for enthusiastic and able research assistance.

1. Gwenda Blair, '70s Portrait of Harlem, Gathered For Today, N.Y. TiMES, July 29, 2012, at A19, available at http:/www.nytimes.com/2012/07/29/arts/design/dawoud-beys-portrait-of-70s-harlemgathered-for-today.html.

2. Id.

3. Id.

4. This is true given that one meaning of "grace" is synonymous with "mercy." The late Professor William J. Stuntz wrote eloquently about the impact of grace as a foundation for effective crime policy. See William J. Stuntz, Law and Grace, 98 VA. L. REV. 367, 367-77 (2012) ("Grace and mercy and relationship are transformative, and that truth has practical value for people who think about law, politics, and government.").

5. As discussed infra, there is unfortunately nothing peculiar about the poverty, trauma, mental illness, and racism with which many capital clients live. Yet, the ways in which these social factors impact each person differ. See Mark E. Olive \& Russell Stetler, Using the Supplementary Guidelines for the Mitigation Function of Defense Teams in Death Penalty Cases to Change the Picture in Postconviction, 36 HOFSTRA L. REV. 1067, 1069 (2008). Explanation of the effect of these forces on a client's functioning and behavior is at the heart of a capital defense team's work. See Craig Haney, The Social Context of Capital Murder: Social Histories and the Logic of Mitigation, 35 SANTA ClARA L. REV. 547, 592-94 (1995) [hereinafter Haney, Social Context].

6. Abdul-Kabir v. Quarterman, 550 U.S. 233, 247 n.8 (2007) (quoting Woodson v. North Carolina, 428 U.S. 280, 304 (1976)). 
them the death penalty. ${ }^{7}$ In each case, grace depends on the investigation and presentation of mitigation: a persuasive description of the forces that shape human behavior and that, in some instances, explain behavior that violates law.

At least two normative judgments and one mixed normativedescriptive judgment underlie the arguments presented here. First, individualized, offender-focused sentencing is fairer than uniform, offensebased sentencing. Second, social history evidence of a person's disadvantaged background is relevant to his moral culpability. Third, rehabilitation and offender-focused punishment will be both fairer and more likely to lead to effective crime reduction policy because mitigation will help identify the factors that influence people to engage in behavior that breaks the law. This paper offers arguments in support of all three assumptions.

Consideration of wide-ranging facets of a person's background is elementary to fair and proportionate sentencing. In fact, individualization in sentencing has historically been a core value, in rhetoric if not always in practice. Supreme Court precedent has certainly constitutionalized this principle in capital cases, but the ascent of determinate and guidelinesbased noncapital sentencing has obscured the value of individualization in routine criminal cases. The death penalty's doctrinal exceptionalism, among other institutional barriers, has deterred comprehensive mitigation presentations in noncapital sentencing as lawyers and noncapital sentencing courts focused on literally calculating sentences.

Notwithstanding the doctrinal and institutional hurdles that have diminished the investigation of life history mitigation in noncapital cases, this paper argues there is simply no principled reason that the same circumstances that courts have recognized narrow opportunity and distort the lives of people charged with capital crimes should not be presented to courts sentencing people for lesser offenses. Moreover, in a departure from the last few decades' emphasis on determinate sentencing, recent Supreme

7. See Mark E. Olive, Narrative Works, 77 UMKC L. REV. 989 (2009) (summarizing three habeas grants of capital sentencing relief based on life history mitigation that was not presented at trial). I won habeas relief in one of the three cases, that of Herbert Williams, Jr., who had been sentenced to death in Alabama. Williams v. Allen, 542 F.3d 1326 (11th Cir. 2008). See Russell Stetler, The Mystery of Mitigation: What Jurors Need to Make a Reasoned Moral Response in Capital Sentencing, 11 U. PA. J.L. \& SoC. CHANGE 237, 238 (2007-2008) (citing the cases of "beltway sniper" Lee Boyd Malvo, 9/1 1 hijacker Zacarias Moussaoui, and Oklahoma City bomber Terry Nichols as three infamous cases that resulted in life verdicts); see Alex Kotlowitz, In the Face of Death, N.Y. TMES MAGAZINE, July 6, 2003 , for a detailed discussion of the capital mitigation resulting in a life sentence for Jeremy Gross, who at eighteen robbed and shot to death a convenience store clerk, and including the following information: the crime was videotaped, guilt was not at issue, an Indiana jury saw the crime video, and nevertheless the jury sentenced Gross to life after hearing details of his neglectful and abusive childhood. See also Carol S. Steiker \& Jordan M. Steiker, Entrenchment and/or Destabilization? Reflections on (Another) Two Decades of Constitutional Regulation of Capital Punishment, 30 LAW \& INEQ. 211, 233 (2012) [hereinafter Steiker \& Steiker, Entrenchment] (explaining that "extensive mitigation cases ... . reflect the new reality that no crimes, no matter their severity, are invariably punished by death"). 
Court decisions have revitalized individualization in noncapital sentencing and made more room for meaningful mitigation presentations in noncapital cases. ${ }^{8}$ Given this opportunity for individualized sentencing to return to the fore, defense lawyers should be doing a great deal more mitigation work. The time has come for noncapital defense lawyers to chart a course toward meaningful individualization by routinely putting life history mitigation at the center of sentencing. There are plenty of better noncapital sentencing practices than the current model that prevails. Capital practice norms can serve as a model, and institutions such as holistic defender offices and law school clinics are particularly well-situated to lead the way.

\section{Context, Implications, and Overview}

This reflection comes at a time when sentencing trends that even a few years ago seemed intractable appear to be giving way to a more merciful approach to punishment. The number of death sentences is falling historically and dramatically ${ }^{9}$ and, for the first time in forty years, the incarceration rate is leveling and, in some states, declining. ${ }^{10}$ Yet, exploration of what might facilitate or accelerate the drop in incarceration rates has, in many respects, remained obscured by capital cases' outsized place in criminal justice practice and policy and in discourse about crime and punishment. ${ }^{11}$ Reasons for the attention devoted to capital cases include the unparalleled gravity and irreversibility of the death penalty and the incalculable human rights impact of the United States' singular commitment to capital punishment among Western democracies. However, the fact remains that the vast majority of criminal defendants are in prison for noncapital crimes, and many are facing prison terms that in regimes without capital punishment would stand out as their own human rights violations. ${ }^{12}$ In 2011 , there were 43 executions and 3,251 people on death

8. See infra notes $91,93-96$ and accompanying text.

9. 2011 marked the first time since the death penalty was reinstated in 1976 that there were fewer than 100 new death sentences annually. See The Death Penalty in 2011: Year End Report, DEATH PENALTY INFORMATION CENTER (2011) [hereinafter DPIC Report]. See also Ethan Bronner, Use of Death Sentences Continues to Fall In US, N.Y. TIMES, Dec. 21, 2012, at A24 (reporting that in 2012 there were eighty death sentences, one third the number reported in 2000).

10. David Cole, Turning The Corner On Mass Incarceration?, 9 OHIO ST. J. CRIM. L. 27, 29 (2011).

11. Carol S. Steiker \& Jordan M. Steiker, Opening a Window or Building a Wall? The Effect of Eighth Amendment Death Penalty Law and Advocacy on Criminal Justice More Broadly, 11 U. PA. J. CONST. L. 155, 190 (2008) [hereinafter Steiker \& Steiker, Opening a Window].

12. This is particularly true of life without parole (LWOP) sentences, which are often adopted by death penalty advocates as a means of reducing the likelihood of death sentences, but which are rarely imposed in many other parts of the world. In the absence of capital punishment, LWOP would be a very viable target of human rights campaigns and Eighth Amendment litigation. See Steiker \& Steiker, Entrenchment, supra note 7, at 234. In fact, reduction in death sentences is often linked to the availability of life without parole as an alternative, which is a cardinal example of the ways in which maintenance of the death penalty promotes draconian criminal punishment broadly. See Steiker \& Steiker, Opening a Window, supra note 11, at 176-77; Aman Batheja, Texas Sends Fewer to Death Row, CHI. TRIB. (Nov. 28, 2009), http://articles.chicagotribune.com/2009-11- 
row; ${ }^{13}$ in 2010 , by comparison, there were 2.3 million people in U.S. prisons and jails, with all but approximately 3,200 of them serving noncapital sentences. ${ }^{14}$ As the death penalty appears to be falling out of favor, ${ }^{15}$ there is hope that incarceration rates are also waning. It is worthwhile to consider how the work that has contributed to capital punishment's decline might be deployed to ameliorate noncapital penalties. Effective presentation of capital mitigation has both changed sentencers' perceptions of individual defendants and recalibrated prevailing views of criminality as a product of individual poor choices rather than the range of social factors that influence human behavior. ${ }^{16}$

The same circumstances that impact many capital defendants' lives-including poverty, untreated or self-treated mental illness, addiction, and trauma - also affect many noncapital defendants' lives. ${ }^{17}$ Yet, there is no constitutional imperative that noncapital defendants' sentencers hear evidence that the Supreme Court has recognized as central to "assessing a defendant's moral culpability." 18 A person convicted of a noncapital crime has no right to have his sentencer consider his individual circumstances in

28/news/0911280167_1_death-sentences-death-row-juries (citing prosecutors and defense attorneys as identifying "the biggest game changer" in Texas' death penalty rates as the introduction of life without parole in 2005). From another vantage point, the death penalty leads to "sentence inflation" so that if the most aggravated homicides are punishable by death, then lesser, but still quite serious, crimes must be punishable by the next harshest penalty available: LWOP. See also Cole, supra note 10, at 41 ("Today, one out of eleven [American] sentences being served is a life sentence. For the same types of crimes, American sentences are roughly twice as long as those in the United Kingdom, four times longer than those meted out by the Dutch, five times longer than those in Sweden, and five to ten times longer than those imposed in France."). There have been successful Supreme Court challenges to the application of LWOP to juveniles, particularly very young teenagers, but no similar challenges to LWOP's constitutionality for adult offenders. See, e.g., Miller v. Alabama, 132 S. Ct. 2455 (2012); Jackson v. Hobbs, 132 S. Ct. 1733 (2012); Graham v. Florida, 560 U.S. 48 (2010).

13. DPIC Report, supra note 9.

14. Bureau of Justice Statistics, U.S. Correctional Population DeClined For Second CONSECUTIVE YEAR (2011), available at http://bjs.ojp.usdoj.gov/content/pub/press/p10cpus10pr.cfm.

15. A 2012 ballot referendum to abolish the death penalty in California lost by about six percentage points. Howard Mintz \& Matt O'Brien, Proposition 34: Death Penalty Repeal Fails, SAN JOSE MERCURY NEWS (Nov. 6, 2012), http://www.mercurynews.com/elections/ci_21943752/californiaproposition-34-voters-decide-whether-keep-states.

16. See Haney, Social Context, supra note 5, at 561-62 ("Capital penalty trials . . and what they tell us about the roots of violence ... can . . . serve as the basis for development of a responsible social policy of violence prevention ... ."). See also Mona Lynch \& Craig Haney, Looking across the Empathic Divide: Racialized Decision Making on the Capital Jury, MICH. ST. L. REV. 573, 590 (2011); Stetler, supra note 7 , at 264 (describing mitigation as having a purpose outside the courtroom as "an archive for future historians, social scientists, and public health researchers who will look for the causes of the homicide levels in twenty-first century America ....").

17. Stetler, supra note 7 and text accompanying notes 7,16 (describing studies documenting the prevalence of mental illness among capital and noncapital prisoners). It is also entirely possible that the degrees or types of mental illness, trauma, addiction, and other prototypical capital mitigation are simply not as prevalent among noncapital offenders. One implication of pushing for more investigation and presentation of whatever mitigation is present in noncapital cases is the accrual of a record of the social circumstances that actually do contribute to noncapital crime. Another research project might center on identifying and distinguishing the social histories of some set of noncapital defendants from those of capital defendants.

18. Wiggins v. Smith, 539 U.S. 510,512 (2003). 
mitigation..$^{19}$ As a result, thousands of people are sentenced to thousands of years of prison annually by judges who know very little, if anything, about their backgrounds, including factors that should be considered in any just assessment of their blameworthiness. Given the doctrinal barriers to successful postconviction proportionality challenges of long prison sentences, ${ }^{20}$ accounting for all possible mitigating factors at the outset of sentencing is the best hope for stemming overly harsh punishment. ${ }^{21}$ Institutional change in defense sentencing advocacy is a logical next step.

A good deal has been written about mitigation in capital sentencing ${ }^{22}$ as well as the merits of individualized noncapital sentencing. ${ }^{23}$ Articles have also examined reasons and presented proposals to explain declining incarceration rates $^{24}$ and compared implications of capital and noncapital Eighth Amendment doctrine. ${ }^{25}$ Other scholarship has considered the contours of Sixth Amendment challenges to defense representation at noncapital sentencing. ${ }^{26}$ This paper touches on these areas and proposes something new: ${ }^{27}$ One way of accelerating the decline in incarceration rates

19. See Harmelin v. Michigan, 501 U.S. 956, 994-95 (1991). Harmelin-which challenged a mandatory life without parole sentence imposed on a first-time felony offender convicted of possessing 672 grams of cocaine-is an Eighth Amendment case decided mostly on proportionality grounds. Professor Rachel Barkow has criticized the Supreme Court's proportionality doctrine in noncapital sentencing, which is not the focus of this article. See Rachel Barkow, The Court of Life and Death: The Two Tracks of Constitutional Sentencing Law and The Case For Uniformity, 107 MiCH. L. REV. 1145, 1155-62 (2009) (arguing that the Supreme Court is not as robust in its proportionality review of noncapital sentences as it is with capital sentences). Mitigation concerning a defendant's life circumstances, including those that influenced his behavior leading up to criminal charges, is certainly relevant to the Supreme Court's threshold proportionality test for noncapital sentences which asks whether "the sentence is grossly disproportionate to the crime" and will uphold a sentence "as long as the state has a 'reasonable basis for believing' that it will serve either deterrent, retributive, rehabilitative, or incapacitative goals." Id. at 1156-57 (quoting Ewing v. Califomia, 538 U.S. 11, 28 (2003)). One can hardly determine whether a prosecutor's belief that a sentence will meet one of those enumerated penological goals is reasonable without knowing anything about the individual who will be serving that sentence.

20. See Steiker \& Steiker, Opening a Window, supra note 11, at 186-87 (discussing Harmelin, 501 U.S. 957).

21. See Barkow, supra note 19, at 1155-62 (noting that the United States Supreme Court upholds seemingly disproportionate sentences in noncapital cases if the state has a reasonable belief that such a sentence will advance a "deterrent, retributive, rehabilitative, or incapacitative goal").

22. See, e.g., Haney, Social Context, supra note 5, at 589-90; Stetler, supra note 7, at 238; Kathleen Wayland, The Importance of Recognizing Trauma Throughout Capital Mitigation Investigations and Presentations, 36 HOFSTRA L. REV. 923, 926-28 (2008).

23. See, e.g., Craig Haney, Politicizing Crime and Punishment: Redefining "Justice" to Fight the "War on Prisoners," 114 W. VA. L. REV. 373, 384-85 (2012) [hereinafter Haney, War on Prisoners]; Dhammika Dharmapala et al., Legislatures, Judges, and Parole Boards: The Allocation of Discretion under Determinate Sentencing, 62 FLA. L. REV. 1037, 1050 (2010); Barkow, supra note 19 at 1155-62.

24. See, e.g., Cole, supra note 10, at 34-43; Mary D. Fan, Beyond Budget-Cut Criminal Justice: The Future of Penal Law, 90 N. C. L. REV. 581, 583-86 (2012).

25. See Fan, supra note 24, at 608-10; Barkow, supra note 19.

26. See, e.g., Carissa Byrne Hessick, Ineffective Assistance At Sentencing, S0 B.C. L. REV. 1069, 1072 (2009).

27. The survey of professional noncapital sentencing guidelines discussed infra Part IV is also a new contribution to scholarship on sentencing and lawyers' professional and ethical obligations to their 
is to make the kind of mitigation that has contributed to the unprecedented reduction in capital sentences central to noncapital sentencing as a means of preventing and challenging excessively punitive sentences. ${ }^{28}$ Professor David Cole has suggested that an "empathy gap" that arises from the failure of most Americans to have much concern about the lives of those behind bars is one of the biggest challenges to increasing public will for meaningful prison reform. ${ }^{29}$ This article urges noncapital defense lawyers to provide a factual basis for bridging that gap so that sentencers pay closer attention to the human beings whose lives they are being asked to shut away.

Increased emphasis on mitigation will certainly stand to benefit individual defendants. In addition, meaningful mitigation presentations have the collective potential to establish a record of the reasons people engage in criminal behavior, as these presentations have done in capital cases. ${ }^{30}$ That record stands to alter the balance of our understanding of the root causes of crime and to diminish the appetite for unduly harsh punishment. $^{31}$

Proposing that mitigation play a central role in noncapital sentencing implicates a number of complex issues, some of which this paper touches on and some of which are outside its scope. The biggest implication is the Supreme Court's general rejection of Eighth Amendment challenges to noncapital sentencing. ${ }^{32}$ Resources are a second difficult implication, and this paper presents reasons for institutional defender offices to direct resources to develop or strengthen the mitigation practice as well as for foundations and public funding sources to support this work. Holistic public defender offices have been leading the charge in incorporating social workers into their sentencing work and can continue to serve as training centers and models for other practices. ${ }^{33}$ Law school clinics are another prospective source of talent and an important incubator for future lawyers and judges trained in high quality noncapital sentencing advocacy. However, the focus on defenders does not address another difficult institutional issue: the widespread cost of individualized sentencing

clients.

28. See Miller v. Alabama, 132 S. Ct. 2455 (2012); Jackson v. Hobbs, 132 S. Ct. 1733 (2012); Graham v. Florida, 560 U.S. 48 (2010); Roper v. Simmons, 543 U.S. 551, $567-69$ (2005). One scholar has proposed that sentencers should consider the fact of mass incarceration itself a mitigating factor. See, e.g., Anne R. Traum, Mass Incarceration at Sentencing, 64 HASTINGS L.J. (No. 2) 423, 458 (2013).

29. See Cole, supra note 10 , at 40.

30. This is another idea I do not have the space to consider here, but that could certainly be the basis of future research and scholarship. It is also an area that would lend itself well to collaboration with a law school clinic where students would provide direct representation and collect data on mitigating factors that could be reported and used to advocate for non-incarceration dispositions and support for social services addressing issues that recur in sentencing. As discussed infra, this approach would work particularly well in a neighborhood-based office where social problems are concentrated and service agencies are in close proximity.

31. See Haney, Social Context, supra note 5, at 608.

32. See discussion infra Part V.C.

33. See infra text accompanying note 178 . 
on other actors in the justice system, specifically judges and prosecutors. Certainly, more robust defense sentencing presentations will take more time to consider and rebut and will impact judicial and prosecutorial dockets. On the other hand, the high fiscal and incalculable social cost of overly harsh incarceration is well-documented, and this proposal seeks to lessen that institutional toll.

A third implication involves changes to the professional guidelines for noncapital sentencing practice, which, as described in Part IV, call for basic mitigation presentations. These presentations are a far cry from the specific and layered exhortations of the capital guidelines. One reason for the prescriptive focus here on defense lawyers, as opposed to courts or legislatures, is that defense lawyers with adequate resources have the power to work immediately toward bringing about fundamental changes in each of the areas implicated. With a coordinated strategy, defenders can challenge noncapital constitutional doctrine, as they have successfully in Miller $v$. Alabama and Jackson v. Hobbs, discussed infra. Defenders also have the capacity, demonstrated over years of capital practice, to align their professional guidelines with advocacy that brings about more proportional and just sentencing. A fourth implication is reform of mandatory or determinate sentencing schemes that by design exclude consideration of any individual circumstances. ${ }^{34}$

Another acknowledgment: much of the discussion herein centers on federal cases simply because the United States presents a single jurisdictional case study reflecting sentencing trends also seen in many states. ${ }^{35}$ Surveying state statutes and practice is beyond the scope of this project. However, the proposals here for changes in defense sentencing practice are meant for defense lawyers in all jurisdictions, particularly given that the vast majority of sentences are imposed by state courts.

Finally, this paper is not advocating blurring the line between capital and noncapital cases, ratcheting down the standard of death penalty practice, or diminishing procedural and substantive safeguards applicable to capital litigation. To the contrary, the suggestion here is that if there is a single area in which decades of death penalty law and practice might help noncapital defendants, it is by raising the bar and aligning noncapital mitigation practice with the highest standards of the legal profession developed by capital defense teams.

The next part of this paper provides a brief review of the evolution of capital mitigation, including the development of rigorous professional norms for competent representation following Eighth Amendment doctrine

34. See Haney, War on Prisoners, supra note 23, at 375, 385 (noting that "nothing else beyond the 'seriousness of the offense' was thought to matter to the fairness of the sentence"); see also Dharmapala et al., supra note 23, at 1043-44.

35. See, e.g., Michael Tonry, The Mostly Unintended Effects of Mandatory Penalties: Two Centuries of Consistent Findings, 38 CRIME \& JUST. 65 (2009) (summarizing research on mandatory sentencing laws, with a specific focus on laws in the U.S.). 
requiring individualized capital sentencing. Part IV will review the existing professional guidelines for the investigation and presentation of mitigation in noncapital cases, which are less specific than the capital guidelines but establish the elementary steps a defense attorney must take to provide competent sentencing advocacy. Part V presents some of the institutional and doctrinal barriers to more robust noncapital mitigation. This section also explains why in light of these barriers, especially the Supreme Court's adherence to the "death is different" doctrine, noncapital defense attorneys must seize the initiative to improve their mitigation practices and thereby contribute to the paradigmatic shift toward more rehabilitative, individualized noncapital sentencing. This shift hopefully will result in more proportional sentences and fewer and shorter prison terms.

The paper concludes with a case illustrating the inherent value in putting a client's history into the record of an official tribunal before she becomes yet another incarceration statistic, particularly when the client's criminal involvement is, as is often the case, attributable at least as much to social institutional failures as it is to her individual choice to commit crime. In this way, the work capital litigators do to inspire mercy can be applied to noncapital cases to adjust sentencers' views of defendants' moral culpability and to prevent unduly harsh punishment.

\section{The Development of Mitigation as the Crux of Capital Sentencing}

\section{A. A Brief Review of Foundational Supreme Court Eighth Amendment Precedent in Capital Cases}

In the years after the Supreme Court upheld the constitutionality of capital statutes requiring "guided discretion," 36 the Court decided the cases that laid the foundation of modern capital litigation, including the investigation and presentation of mitigating factors to provide a basis for life sentences. ${ }^{37}$ These cases set forth the minimum Eighth Amendment considerations required of sentencers deciding whether to condemn a person to die. First, in striking down North Carolina's mandatory death penalty for first-degree murder, the Court identified one of the state statute's constitutional shortcomings as "its failure to allow the particularized consideration of relevant aspects of the character and record of each convicted defendant before the imposition upon him of a sentence of death." ${ }^{38}$ Two years later, the Court held in Lockett v. Ohio that the

36. See Gregg v. Georgia, 428 U.S. 153 (1976). Four years before Gregg, in Furman v. Georgia, 408 U.S. 238 (1972), the Supreme Court found that all the capital statutes then in place allowed capital sentencers unfettered discretion in deciding which defendants would be sentenced to death. The Court held that unguided discretion violated the Eighth and Fourteenth Amendments, thus halting all executions until the Court decided Gregg. The modem era of capital punishment, including the development of bifurcated capital trials with a guilt phase and a separate penalty phase, followed Gregg.

37. See Eddings v. Oklahoma, 455 U.S. 104 (1982); Lockett v. Ohio, 438 U.S. 586 (1978); Woodson v. North Carolina, 428 U.S. 280 (1976).

38. Woodson, 428 U.S. at 303. 
Eighth and Fourteenth Amendments require that capital sentencers "not be precluded from considering as a mitigating factor, any aspect of a defendant's character or record and any of the circumstances of the offense that the defendant proffers as a basis for a sentence less than death." 39 The Supreme Court refined its description of mitigating circumstances in Eddings v. Oklahoma, reversing the Oklahoma court for failing to consider evidence of Eddings' life history as mitigation because, in the Oklahoma court's view, the evidence "did not tend to provide a legal excuse from criminal responsibility." 40 The Court held that in a capital case, courts may not refuse to consider as a matter of law any relevant mitigating evidence. ${ }^{41}$ Eddings had offered evidence of his youth, of "a difficult family history and of emotional disturbance," which was, even by that relatively early time following the reinstatement of the death penalty, "typically introduced by defendants in mitigation." 42 The Court held that "the background and mental and emotional development of a youthful defendant [must] be duly considered in sentencing," ${ }^{\prime 43}$ and scores of cases since Eddings have made plain that, regardless of the defendant's age at the time of the offense, his social history and mental conditions are textbook mitigation. ${ }^{44}$ Post-offense good conduct is also relevant, ${ }^{45}$ and will be particularly relevant in noncapital cases where redemption and prospects for rehabilitation are central sentencing considerations.

These baseline cases establish that capital sentencers must have an opportunity to give-and are required to give-" "full consideration of evidence that mitigates against the death penalty [in order to] give a reasoned moral response to the defendant's background, character, and crime." ${ }^{.46}$

\section{B. A Brief Review of Supreme Court Sixth Amendment Precedent in Capital Cases}

Following these Eighth Amendment cases, leading capital defense lawyers' practices evolved to emphasize investigation and presentation of wide ranging social history mitigation. Post-Lockett, competent capital defense practice depended on finding evidence that explained defendants'

39. Lockett, 438 U.S. at 604 (emphasis in original).

40. Eddings, 455 U.S. at 113.

41. Id. at 114 .

42. Id. at 115 .

43. He was sixteen at the time of the crime. Id. at 116.

44. See Abdul-Kabir v. Quarterman, 550 U.S. 233, 245 (2007) (holding that the trial court erred in not permitting the sentencing jury to consider mitigating evidence, such as petitioner's troubled childhood); Tennard v. Dretke, 542 U.S. 274, 287 (2004) (finding that evidence of impaired intellectual functioning is inherently mitigating); Wiggins v. Smith, 539 U.S. 510,535 (2003) (holding that defense counsel failed to meet professional standards by not presenting mitigating evidence of defendant's troubled history at trial); Penry v. Lynaugh, 492 U.S. 302, 328 (1989) (taking into consideration defendant's mental retardation and abused background).

45. Skipper v. South Carolina, 476 U.S. 1 (1986).

46. Penry, 492 U.S. at 328 (internal quotation marks omitted) (emphasis in original). 
actions and described the factors that influenced their behavior. After this shift in capital defense practice took hold, the professional guidelines governing that practice began to reflect the new emphasis on mitigation. Perhaps unsurprisingly, in the wake of these evolving professional norms, the next wave of Supreme Court capital mitigation cases pertained to capital defense lawyers' Sixth Amendment duty of competent representation. A trio of decisions from the early 2000 s set forth the constitutional standards required of capital defense lawyers at sentencing. Williams $v$. Taylor, ${ }^{47}$ Wiggins v. Smith, ${ }^{48}$ and Rompilla v. Beard ${ }^{49}$ underscored the breadth of available capital mitigation and counsel's duty to investigate and present a social history in order to provide juries and judges with the information they need to make a decision guided by the "reasoned moral response" required by Woodson, Lockett, and Eddings. ${ }^{50}$ Williams, Wiggins, and Rompilla also made plain that capital defendants' "excruciating life histor[ies]"51 had moved members of the Court to decide that those histories warranted sentencing relief even in cases involving unspeakable offenses. ${ }^{52}$ For example, the Williams Court provided in a footnote a textured glimpse into Williams' squalid early life, including his experience of being left naked in a house with standing urine in the bedrooms and human excrement on the floors by parents too drunk to find clothes to dress him:

The home was a complete wreck ... . There were several places on the floor where someone had had a bowel movement. Urine was standing in several places in the bedrooms. There were dirty dishes scattered over the kitchen, and it was impossible to step any place on the kitchen floor where there was no trash .... The children were all dirty and none of them had on under-pants. Noah and Lula were so intoxicated, they could not find any clothes for the children, nor were they able to put the clothes on them .... The children had to be put in Winslow Hospital, as four of them, by that time, were definitely under the influence of whiskey. ${ }^{53}$

Details were provided through unassailable documentary evidence and were

47. 529 U.S. $362(2000)$.

48. 539 U.S. $510(2003)$.

49. 545 U.S. 374 (2005).

50. See also Abdul-Kabir v. Quarterman, 550 U.S. 233, 264-65 (2007).

51. Wiggins v. Smith, 539 U.S. 510,537 (2003).

52. See e.g. Olive \& Stetler, supra note 5, at 1069 (describing Terry Williams killing of a drunk man by beating his chest and back with a garden tool and stealing three dollars from the victim's wallet leaving him gasping for breath; assaulting two elderly women after this murder and leaving one in a vegetative state; and setting his jail cell afire while being held before his capital trial); Id. at 1071 (describing Kevin Wiggins driving the car and pawning the belongings of the drowned seventy-sevenyear-old victim whose apartment he had robbed); Id. at 1072 (describing Ronald Rompilla's victim as having been stabbed multiple times, including sixteen wounds to his head and neck, beaten with a blunt object, left dead in a pool of his own blood, and set on fire).

53. Williams v. Taylor, 529 U.S. 362, $395 \mathrm{n} .19$ (2000) (citation and internal quotations omitted). 
likely outside the memories of any of those present at the time. That indelible portrait was at the heart of the Supreme Court's grant of sentencing relief. ${ }^{54}$ Similarly, in Wiggins the postconviction record reflected, among other horrors, that Wiggins had suffered severe physical and sexual abuse in a series of foster homes and at the hands of his sadistic alcoholic mother, who left him and his siblings "alone for days with nothing to eat, forcing them to beg for food and to eat paint chips and garbage." 55 And in Rompilla, the postconviction record included the following evidence: Rompilla's father would lock Rompilla and his brother in an excrement-filled dog pen; his mother drank while she was pregnant with him; his father beat Rompilla severely with his hands, fists, leather straps, belts, and sticks; the family had no indoor plumbing; the children slept in an attic with no heat and went to school filthy and in rags; and that Rompilla suffered from organic brain damage and from an "IQ in the mentally retarded range. $" 56$

These details of the particular terrors endured long before these people became capital defendants are seared into the memories of anyone who has read their cases. It is not just that these children were neglected or abused. It is that they were left with nothing to eat but garbage and paint chips; that they were brutalized with leather straps, belts, and sticks; and that they were housed alongside human and canine waste. ${ }^{57}$ Persuaded by these documented atrocities on the lives of children who grew up to be involved in capital offenses, the Supreme Court in Williams, Wiggins, and

\section{Id. at 395 .}

[Trial counsel] failed to conduct an investigation that would have uncovered extensive records graphically describing Williams' nightmarish childhood, not because of any strategic calculation but because they incorrectly thought that state law barred access to such records. Had they done so, the jury would have learned that Williams' parents had been imprisoned for the criminal neglect of Williams and his siblings, that Williams had been severely and repeatedly beaten by his father, that he had been committed to the custody of the social services bureau for two years during his parents' incarceration (including one stint in an abusive foster home), and then, after his parents were released from prison, had been returned to his parents' custody.

Id.

55. Olive \& Stetler, supra note 5, at 1071.

56. Olive \& Stetler, supra note 5, at 1072-73 (internal quotations omitted).

57. There are scores of lower court habeas decisions recounting brutal life histories that have been bases of capital habeas relief. For a few powerful examples, see Olive, supra note 7, at 10, 19-21. Herbert Williams, Jr., for example, endured a childhood full of terror and suffered beatings so severe that his bone was exposed. See Williams, 542 F.3d at 1334. The circuit court relayed additional details of Williams' trauma. His father broke a chair over his head at age seventeen. Id. at 1333. He watched as his father threw his two-year-old brother against a wall with such force that his brother did not speak again for over three years. Id. at 1332 . His mother participated in his father's brutality, and both parents neglected Williams' most basic needs. Id. at 1334 . He did not learn that people brushed their teeth daily until he was incarcerated for his capital offense. Id. at 1334. Abusive and impoverished childhoods are unfortunately far from unique in the lives of capital defendants or prisoners. The details of each person's social history are the elements of successful mitigation. General statements about trauma and poverty are no substitute for these credible narratives offering views into the forces that shaped the lives of people later tried or convicted for capital homicides. 
Rompilla made unequivocal capital trial counsel's duty to develop and present social history mitigation, using prevailing professional norms as a touchstone for whether counsel's performance met the appropriate standard of care. ${ }^{58}$ A review of the evolution of those norms follows.

\section{Development of Mitigation as Standard Capital Defense Practice}

Once the Supreme Court made clear that the presentation and consideration of mitigation must be a part of any constitutionally permissible capital trial, lawyers defending capital clients set about the task of identifying the factors that would humanize their clients, explain their behavior, and give judges and juries a reason to sentence them to life. ${ }^{59}$ Successful presentation of mitigation requires going outside the relatively narrow categories of mitigation prescribed by many capital statutes, and instead speaking of the "diverse frailties of humankind" as the source of mercy. ${ }^{60}$ Mitigation should inspire recognition of common humanity and bridge the divides between an indigent person presumed to be a deranged, inscrutable killer, and the good citizens who sit in judgment of him. ${ }^{61}$ Mitigation includes "any aspect of a defendant's character or record and any of the circumstances of the offense that the defendant proffers as a basis for a sentence less than death." 62

With this definition of mitigation firmly established, intrepid and creative capital defense lawyers ${ }^{63}$ nationwide set about unearthing and presenting a credible narrative of the factors that landed the client before the sentencer choosing life or death. ${ }^{64}$ Capital defense lawyers began to work with investigators ${ }^{65}$ whose sole responsibility was to uncover evidence of

58. See Wiggins v. Smith, 539 U.S. 510, 524 (2003) (calling the ABA Guidelines "well-defined norms"); see also Olive \& Stetler, supra note 5, at 1074-75 (discussing the Supreme Court's use of the Guidelines in recognizing capital counsel's "long-recognized 'obligations' and the parameters of attorney 'diligence"').

59. Stetler, supra note 7 , at 237-38.

60. Woodson v. North Carolina, 428 U.S. 280, 304 (1976).

61. As Russell Stetler, a leading light among mitigation specialists, has written:

The diverse frailties bestow the kinship of humanity. We all have them, to varying degrees, but, for most of us, the protective supports of family and society along with our individual strengths offset those frailties. For many capital clients, the frailties are overwhelming, and the supports are absent. Eighth Amendment jurisprudence confers compensatory protection to allow life-and-death decision makers to extend compassion on an individual basis.

Stetler, supra note 7 , at 241 .

62. Skipper v. South Carolina, 476 U.S. 1, 4 (1986) (internal citation omitted).

63. See, e.g., Sean D. O'Brien, Capital Defense Lawyers: The Good, the Bad, and the Ugly, 105 MICH. L. REV. 1067 (2007) (reviewing Professor Welsh S. White, Litigating IN THE Shadow of DeATH: DefEnSE ATtorneys in CAPITAL CaSes (2006)).

64. See O'Brien, supra note 63, at 1081-82 (emphasizing that "the capital defense bar will always reach out for help and advice from multiple sources" "to unearth sources of human compassion in their cases").

65. See Stetler, supra note 7, at 248-54 (providing a history of the introduction of mitigation specialists into capital defense teams). 
disabilities, mental conditions, and social influences that served as "a basis for compassion-not an excuse." 66 These "mitigation specialists" became essential members of capital defense teams. ${ }^{67}$ The mitigation specialist's role is to compile a comprehensive social history and identify mitigating themes. Mitigation specialists also assist counsel in locating appropriate experts and providing the defendant's social history data to allow the experts to reliably evaluate the client. Counsel, the mitigation specialist, and the experts then work together to develop a comprehensive case for mercy. ${ }^{68}$ As a consequence of the Supreme Court's post-Furman Eighth Amendment jurisprudence, even the most death-prone jurisdictions came to expect this socio-legal data known as mitigation in capital proceedings.

After capital defense lawyers had some time to develop that new baseline standard of practice meeting the requirements of Lockett, Eddings. and related cases, written professional guidelines coalesced and reflected the work capital defense teams were doing to put together life-saving, credible portraits for mercy and to guide more lawyers to raise their level of practice to meet basic standards. ${ }^{69}$ In 1989, the American Bar Association (ABA) first published the Guidelines for the Appointment and Performance of Counsel in Death Penalty Cases. ${ }^{70}$ Fourteen years later, in 2003, the ABA revised the guidelines to take into account intervening legal developments and "to provide specific guidance to remedy some of the most serious mistakes made by counsel and other actors in the criminal justice system." 71 In particular, the 2003 Guidelines reflected the Supreme Court's emphasis on individualized capital sentencing ${ }^{72}$ and crystallized the corresponding professional obligation to employ mitigation specialists at all

66. Id. at 262 .

67. Id. at 250

68. Id. at 245 (citing American Bar Association, American Bar Association Guidelines for the Appointment and Performance of Defense Counsel in Death Penalty Cases, 31 HofSTRA L. REV. 913 , 959 (2003)).

69. The ABA Guidelines' history makes clear that the professional standards have both reflected the most competent capital representation being contemporaneously provided and served as an aspirational beacon for lawyers falling short of that standard. See also Olive \& Stetler, supra note 5, at n.39 "The Supreme Court has consistently used the ABA's standards and guidelines in capital cases to assess the performance of trial counsel who prepared their eases [sic] before the relevant $A B A$ publications had been issued.") (internal citation omitted).

70. See Robin M. Maher, The ABA and the Supplementary Guidelines for the Mitigation Function of Defense Teams in Death Penalty Cases, 36 HOFSTRA L. REV. 763, 766 (2008).

71. Id. In the years immediately preceding adoption of the ABA Guidelines, two Supreme Court justices-Justice O'Connor and Justice Ginsburg-had also expressed concern about the quality of defense representation in capital cases making their way to the high court. Brian Bakst, $O^{\prime}$ Connor Says There Are "Serious Questions" About Fairness of The Death Penalty, ASSOCIATEd PRESS (July 3, 2001) http://lubbockonline.com/stories/070301/upd_075-4394.shtml; see also Ruth Bader Ginsburg, Associate Justice, United States Supreme Court, Address at U.D.C. School of Law (Apr. 9, 2001), available at http:/www.supremecourt.gov/publicinfo/speeches/viewspeeches.aspx?Filename=sp_04-09-01a.html (Justice Ginsburg opining in a speech at the University of the District of Columbia David A. Clarke School of Law that she had yet to see a capital case in which the defendant was well-represented at trial).

72. Maher, supra note 70 , at 767 . 
stages of death penalty litigation. ${ }^{73}$ They also required jurisdictions to provide funding for the defense to hire a mitigation specialist in every case. $^{74}$

In the years following the 2003 Guidelines, lawyers and mitigation specialists nationwide developed the Supplementary Guidelines for the Mitigation Function of Defense Teams in Death Penalty Cases to define the nature and scope of mitigation and the qualifications and training of mitigation specialists. ${ }^{75}$ The Supplementary Guidelines are organized to correspond to the $\mathrm{ABA}$ Guidelines and make clear that counsel has the ultimate responsibility for putting together a team that has the skills and tools necessary to provide the client with a comprehensive mitigation investigation. ${ }^{76}$

This history of the development of high-quality capital mitigation standards may be instructive for development of similar norms in noncapital cases. However, there remains a major distinction between the trajectory of capital defense mitigation and noncapital defense mitigation: the former developed in response to the Supreme Court's Eighth Amendment precedent requiring capital sentencing to include meaningful consideration of life history mitigation. No such doctrine applies to noncapital sentencing, so there is no corresponding constitutional mandate for noncapital defense attorneys to pursue mitigation. The one noncapital exception derives from the Supreme Court's holdings in Miller v. Alabama and Jackson v. Hobbs. ${ }^{77}$ Those cases held that mandatory life without parole sentencing of juveniles violates the Eighth Amendment and that individualized sentencing, including consideration of social histories, is required for all juvenile offenders. ${ }^{78}$ The Miller/Jackson cases, the first to extend the requirement of individualized sentencing to noncapital cases, have provided a limited ${ }^{79}$ opening for investigation and presentation of robust noncapital mitigation. In fact, efforts are underway to provide mitigation training for the lawyers who will represent clients receiving resentencing hearings under Miller/Jackson. Yet, outside juvenile cases, in

73. Id. at 770 (citing ABA Guideline 4.1).

74. Id. (citing ABA Guideline 9.1).

75. Though these standards were not developed by the ABA, the organization's Death Penalty Representation Project welcomed them as a "valuable elaboration of the principles embodied in the black-letter ABA Guidelines." Stetler, supra note 7, at 263; see Maher, supra note 70 , at 770 (describing the Supplementary Guidelines as a "natural and complementary extension of the ABA Guidelines").

76. Stetler, supra note 7, at 245-46.

77. Miller v. Alabama, 132 S. Ct. 2455 (2012); Jackson v. Hobbs, 132 S. Ct. 1733 (2012).

78. Miller, 132 S. Ct. at $2468-69$.

79. The Court explicitly distinguished cases involving mandatory LWOP sentencing of juveniles from those involving mandatory LWOP sentencing of adults and affirmed its own holding in Harmelin, v. Michigan, 501 U.S. 956 (1991), when the Court upheld a mandatory LWOP sentence for cocaine possession. See Miller, $132 \mathrm{~S}$. Ct. at 2469-70 (discussing why state arguments against "individualized considerations" in juvenile sentencing to LWOP were not persuasive). See also Fan, supra note 24, at 604-09 (discussing the factors used by Justice Kennedy to distinguish mandatory LWOP sentencing of adults from individualized juvenile LWOP sentencing). 
the vast majority of noncapital cases the presentation and consideration of mitigation remains entirely elective.

The capital defense community has devoted so much attention to capturing and documenting the professional services required to provide clients with effective mitigation because mitigation contextualizes and explains offenses that otherwise remain unfathomable and appear to be attributable to an essential, unchangeable, and irredeemable evil rather than to readily identifiable social forces. ${ }^{80}$ As described in the next section, the same social influences that explain capital crimes in many cases explain noncapital crimes. ${ }^{81}$ The work used to develop an understanding of people who stand before juries and judges convicted of the most serious offenses should certainly be applied to evoke merciful sentencing for people accused or convicted of lesser violations of the law. ${ }^{82}$ That work must begin with defense lawyers applying mitigation to the representation of noncapital clients. The next section describes how, while noncapital defense norms provide broad outlines for competent sentencing advocacy, there is no specific requirement for comprehensive mitigation investigation as there is in capital cases.

\section{Professional Standards of Noncapital Mitigation}

\section{A. Supreme Court Dicta on Individualized Noncapital Sentencing}

In Woodson, the Supreme Court noted that in noncapital cases "the prevailing practice of individualizing sentencing determinations generally reflects simply enlightened policy rather than a constitutional imperative."83 In capital cases, by comparison, "the fundamental respect for humanity underlying the Eighth Amendment" elevated what was only good policy in noncapital sentencing to a constitutional requirement of "consideration of the character and record of the individual offender and the circumstances of the particular offense ...." ${ }^{84}$ The Court quoted Pennsylvania v. Ashe ${ }^{85}$ a noncapital case, in recognizing that "[f]or the determination of sentences, justice generally requires consideration of more than the particular acts by which the crime was committed and that there be taken into account the circumstances of the offense together with the character and propensities of

80. See Haney, Social Context, supra note 5 , at 549 (noting that the criminal system and the media cause American citizens "to view capital defendants as genetic misfits"). See also Stetler, supra note 7, at 248-54 (explaining the importance of collaborative defense work in capital cases). See also California v. Brown, 479 U.S. 538, 545 (1987) (O'Connor, J., concurring) (“'E]vidence about the defendant's background and character is relevant because of the belief, long held by this society, that defendants who commit criminal acts that are attributable to a disadvantaged background, or to emotional and mental problems, may be less culpable than defendants who have no such excuse.").

81. See discussion infra Part IV.F.

82. See Cole, supra note 10 , at $37-39,40$.

83. Woodson v. North Carolina, 428 U.S. 280, 304 (1976).

84. Id.

85. Comm. of Pa. ex rel. Sullivan v. Ashe, 302 U.S. 51 (1937). 
the offender." $" 86$

In Lockett, the Court elaborated on the longstanding recognition that "individualized sentencing in criminal cases generally, although not constitutionally required, has long been accepted in this country." 87 The Court went on to explain that "sentencing judges traditionally have taken a wide range of factors into account .... [a]nd where sentencing discretion is granted, it generally has been agreed that the sentencing judge's possession of the fullest information possible concerning the defendant's life and characteristics is highly relevant if not essential to the selection of an appropriate sentence." 88 The Court underscored that in noncapital cases there was "wide acceptance" for the "the established practice" of individualized sentences and that such practice, though not constitutionally mandated as it was in capital cases, was "public policy enacted into statutes." 89

Capital sentencing continued to move toward individualization while noncapital sentencing, particularly in federal cases but also in many states, ${ }^{90}$ moved toward uniformity with the adoption of the mandatory Federal Sentencing Guidelines. ${ }^{91}$ More recently, however, the Court has reemphasized the importance of individualized noncapital sentencing. ${ }^{92}$ In Pepper v. United States, the Court reaffirmed that "possession of the fullest information possible concerning the defendant's life and characteristics"93 is "highly relevant-if not essential - to the selection of an appropriate sentence." 94 The Court characterized as "uniform and constant" federal sentencing tradition to "consider every convicted person as an individual and every case as a unique study in the human failings that sometimes mitigate, sometimes magnify, the crime and the punishment to ensue. . . Underlying this tradition is the principle that the punishment should fit the offender and not merely the crime." $" 96$

Woodson and Lockett suggest that at one time there was a "prevailing practice" 97 of sentencers taking into account the facts of the offense as well as the "fullest information possible" about the defendant's

86. Woodson, 428 U.S. at 304 (quoting Ashe, 302 U.S. at 55) (internal quotation marks omitted) (emphasis added).

87. Lockett v. Ohio, 438 U.S. 586, 602 (1978) (citing Williams v. New York, 337 U.S. 241, $247-48$ (1949)).

88. Lockett, 428 U.S. at $602-03$ (quoting Williams, 337 U.S. at 247) (internal quotation marks and punctuation omitted).

89. Lockett, 428 U.S. at 605.

90. See, e.g., Tonry, supra note 35.

91. See Pepper v. United States, 131 S. Ct. 1229, 1240-41 (2011).

92. See Blakely v. Washington, 542 U.S. 296, 303 (2004); United States v. Booker, 543 U.S. 220, 245 (2003); Apprendi v. New Jersey, 530 U.S. 466, 490-92 (2000).

93. Pepper, $131 \mathrm{~S}$. Ct. at 1240 (2011) (internal quotation marks and citations omitted).

94. Id. (internal quotation marks and citations omitted).

95. Id. at 1239 (internal quotation marks and citations omitted).

96. Id. at $\mathbf{1 2 4 0}$ (internal quotation marks and citations omitted).

97. Woodson v. North Carolina, 428 U.S. 280, 304 (1976). 
life circumstances and character and that such consideration was essential to enlightened sentencing practice. ${ }^{98}$ The cases also reflect renewed interest in individualized noncapital sentencing, at least among some members of the Court. Yet, the professional norms governing criminal defense lawyers' sentencing practice have not kept pace with such statements concerning the importance of individualized noncapital sentencing. ${ }^{99}$ One possible reason is that historically, all parties have relied on court-based probation and parole departments to provide an "independent" sentencing report for the court to reference in meting punishment. ${ }^{100}$ Another possibility is that because Supreme Court dicta recognized that there was no constitutional imperative for individualized noncapital sentencing, ${ }^{101}$ defense lawyers and courts treated mitigation investigation and presentation as elective, and therefore it never took widespread hold as a core defense duty. In addition, the Federal Sentencing Guidelines prohibited consideration of certain life circumstances, such as poverty or disadvantaged upbringing, in favor of a focus on "real conduct." 102 This prohibition trained most federal criminal defense practice on Guidelines calculation rather than on investigation of sentencing factors that courts were instructed to disregard. This led to an atrophying of noncapital mitigation practice among federal defense lawyers. ${ }^{103}$ However, as Pepper has recognized, the post-mandatory Guidelines era has reopened the opportunity for life history mitigation presentations in federal noncapital sentencing. ${ }^{104}$

While the current guidelines for noncapital defense sentencing advocacy are broad enough to warrant some degree of independent sentencing investigation beyond the data provided by probation departments or prosecutors, they remain a far cry from the capital guidelines' specific prescriptions for comprehensive social history investigation. ${ }^{105}$ There is also a significant gulf between the noncapital guidelines' recommendations for essential sentencing advocacy and prevailing defense practice in many jurisdictions, especially those strapped for resources.

The standards reviewed here are those of the major national professional organizations setting forth practice norms for criminal defense lawyers: the ABA, the National Legal Aid and Defender Association

98. Lockett v. Ohio, 438 U.S. 586, 602 (1978).

99. See generally, Hessick, supra note 26, at 1109-10 (noting that professional standards and substantive law regarding advocacy for noncapital defendants are underdeveloped and "lopsided").

100. Of course this raises the question what, if any, information the defense has been expected to provide to those agencies.

101. Pepper, 131 S. Ct. at $1239-40$.

102. Id. at $1240-41$.

103. See Adriaan Lanni, Jury Sentencing In Noncapital Cases: An Idea Whose Time Has Come (Again)?, 108 YALE L.J. 1775, 1783 (1999) (discussing the Federal Sentencing Guidelines' consideration of various life circumstances as "not ordinarily relevant" to federal sentencing).

104. See Pepper, 131 S. Ct. at 1241.

105. See Hessick, supra note 26 , at 1070,1110 (calling the standards for what constitutes ineffective assistance of counsel in noncapital sentencing proceedings "underdeveloped"). 
(NLADA), and the American College of Trial Lawyers.

B. ABA Criminal Justice Standards

The noncapital ABA sentencing guidelines include the following principles: independent defense investigation of sentencing factors; individualized consideration of sentences; presentation of mitigating factors; and consideration of those factors by the evaluating court. The court should evaluate both the severity of the offense and the culpability of the particular offender. The principal ABA guidelines for noncapital cases are the $A B A$ Criminal Justice Standards, which have existed in various forms for over forty years. ${ }^{106}$ Two subsets of those standards speak most directly to the role of mitigation in noncapital cases: the Defense Function standards, which pertain to defense counsel's professional obligations at sentencing, and the Sentencing standards, which govern the role of legislatures, probation and parole agencies, and courts.

The Defense Function standards describe the basic duties of defense lawyers to investigate and to provide sentencing advocacy, but nowhere do they explicitly describe a duty to investigate mitigation. According to the Defense Function standards, a defense lawyer should conduct a "prompt investigation of the circumstances of the case and explore all avenues leading to facts relevant to ... penalty ...."107 Defense counsel should become familiar with all resources and sentencing alternatives available to the court that may meet the defendant's needs. ${ }^{108}$ Defense counsel should also be familiar with the court's sentencing habits and any applicable guidelines. ${ }^{109}$ Counsel is obligated to explain to the client the consequences of the various available dispositions. ${ }^{110}$ In addition, "[d]efense counsel should present to the court any ground which will assist in reaching a proper disposition favorable to the accused," including recommending rehabilitative programs, ${ }^{111}$ and must verify, supplement, or challenge information in any presentence report made available to the defense. ${ }^{112}$

The second relevant subset of the ABA Criminal Justice Standards, the Sentencing standards, makes recommendations for legislatures, relevant agencies, and sentencing courts. ${ }^{113}$ These standards, unlike the Defense

\footnotetext{
106. About Criminal Justice Standards, AM. BAR Ass'N, http://www.americanbar.org/groups/criminal_justice/standards.html (last updated 2014).

107. Standards for Criminal Justice: Prosecution and Defense FunCtion \& 4-4.1(a) (1993) [hereinafter DEFENSE FUNCTION STANDARDS].

108. Id. at § 4-8.1(a).

109. $I d$.

110. Id.

111. Id. at $\S 4-8.1(\mathrm{~b})$.

112. Id.

113. Standards For Criminal Justice: Sentencing (1994) thereinafter Sentencing STANDARDS].
} 
Function standards, at times explicitly provide for the development, presentation, and consideration of mitigation, but by the "intermediate agencies" and courts, rather than by defense counsel. For example, one Sentencing standard recommends individualization of sentences, ${ }^{114}$ which is consistent with Lockett's recognition that, at least as far back as Pennsylvania v. Ashe and Williams v. New York, sentencing courts have accounted for a wide range of factors that shed light on the "character and propensities" of the offender, not just the offense. ${ }^{115}$ The Sentencing standards urge legislatures to authorize sentencing courts to exercise discretion, taking into account the circumstances of the offense and the characteristics of the offender. ${ }^{116}$

The ABA's Sentencing standards also devote a specific section to "Mitigating Factors" aimed at legislatures and agencies performing the "intermediate function" of identifying relevant sentencing characteristics before sentencing (a function usually performed by probation or parole departments). ${ }^{117}$ The ABA recommends that once mitigating factors have been identified, intermediate agencies ought to guide courts to use their discretion to adjust the sentence accordingly. ${ }^{118}$ Implicit in this recommendation is the recognition that mitigation may impact the sentencer's consideration of the defendant's blameworthiness. Mitigation may contextualize the defendant's actions through applicable mitigating factors, or change the sentencer's view of the offender by providing information about circumstances that set the defendant apart from "the ordinary offender," particularly if those characteristics are ones of hardship. ${ }^{119}$

This principle is longstanding and crucial in capital sentencing, and the ABA guidelines for courts and agencies preparing sentencing profiles affirm that the principle is fundamental to proportional noncapital punishment as well.

Read together, the noncapital ABA standards offer defense counsel and sentencing courts wide latitude to present and consider a range of mitigation, not necessarily directly related to the defendant's criminal culpability, and to use that mitigation to advocate for or impose an alternative or ameliorated sentence. They also establish that the agencies

114. Id. at $\S 18-2.6(\mathrm{a})$.

115. Lockett v. Ohio, 438 U.S. 586 (1978).

116. SENTENCING STANDARDS, supra note 113, at $\$ 18-2.6$ (a)(i)-(ii).

117. Id. at $\S 18-3.2$. For a fuller description of the role of probation departments in preparing presentence investigation reports, see ANTHONY G. AMSTERDAM, TRIAL MANUAL 5 FOR THE DEFENSE OF CRIMINAL CASES 285-86 (Vol. 1 1988).

118. SENTENCING STANDARDS, supra note 113, at § 18-2.6(a)-(b). Moreover, in regimes with presumptive sentences, the guidelines recommend that courts consider mitigating factors in selecting lesser sentences within a presumptive range, or depart downward from the range. Id. at $\S 18-3.2$ (d).

119. Id. at § 18-3.2(b); see also id. at § 18-3.4(c). The standard also requires that all information in presentence reports is accurate, verifiable, and accessible. If it is challenged by either the prosecution or the defense, the preparer of the report must help determine whether the information can be substantiated. Id. at $\$ 18-5.3$. 
tasked with preparing presentence reports have a duty to include mitigation, and courts have a duty to consider mitigation when imposing a punishment.

\section{NLADA Guidelines}

The National Legal Aid and Defender Association (NLADA), an organization representing both civil and criminal defense legal aid attorneys, ${ }^{120}$ likewise has guidelines for defense sentencing representation. The NLADA Guidelines are more specific than their ABA counterparts in describing defense lawyers' duties before and during noncapital sentencing and explicitly require counsel to "ensure all reasonably available mitigating and favorable information, which is likely to benefit the client, is presented to the court[.]"121 The NLADA also recommends the use of "sentencing specialists" in appropriate cases. ${ }^{122}$ Like the ABA standards, the NLADA Guidelines require defense lawyers to be familiar with any sentencing report and to correct misstatements or omissions of helpful sentencing information as well as to be familiar with the relevant law and practice. ${ }^{123}$ The NLADA Guidelines also require defense counsel to develop a plan for achieving the least restrictive sentencing outcome based on the particular client's circumstances ${ }^{124}$ and social history. ${ }^{125}$ The NLADA Guidelines require that counsel, where necessary, specifically request the opportunity to present evidence at the sentencing hearing. ${ }^{126}$ Finally, the NLADA Guidelines provide for a defense sentencing memorandum, which presents another opportunity to challenge inaccurate or incomplete information in the official presentence report, to include information favorable to the defendant, and to make a defense sentencing recommendation. ${ }^{127}$ In short, the NLADA's compendium of defense lawyers' duties at noncapital sentencing is comparatively more robust and more specific than the

120. The NLADA describes itself as "America's oldest and largest nonprofit association devoted to excellence in the delivery of legal services to those who cannot afford counsel" and it "serves as the collective voice for our country's civil legal aid and public defender services." NAT'L LEGAL AID \& DEFENDER ASS'N, http:/www.nlada.org/About/About_Home (last visited Oct. 5, 2013). This is in contrast to the $\mathrm{ABA}$ which is a professional organization representing all attorneys of any specialty, making possible that attorneys other than those practicing criminal defense, and in fact some prosecutors, might have a role in promulgating defense function guidelines. Certainly the adoption of the guidelines by the entire ABA must require the buy-in of current and former prosecutors and judges.

121. PERFormance Guidelines For CRIMINAL DEFENSE REPRESENTATION $§ 8.1$ (a)(3) (Nat'l Legal Aid \& Defender Ass'n 1995) [hereinafter NLADA Guidelines].

122. Id. at $\$ 8.1(\mathrm{a})(6)$.

123. See id. at $\S \S 8.1(\mathrm{a})(2), 8.1(\mathrm{a})(5)$, and 8.2 ; see also id. at $\S 8.4$ (requiring counsel to provide the person preparing the report information favorable to the client and to be familiar with and prepared to challenge any inaccuracies in the official presentence report).

124. Id. at $\S 8.1(\mathrm{a})(4)$.

125. See id. at $\$ 8.3(\mathrm{a})(3)$.

126. Id. at $\S 8.3(\mathrm{a})(9)$; see also id. at $\S 8.7$ (recommending that counsel be prepared to request and present evidence at an evidentiary hearing during sentencing).

127. NLADA Guidelines, supra note 121 , at $\S 8.6(a)(4)$ and $(a)(7)$. The NLADA Guidelines also require counsel to advise the client about avenues for petitioning the court for a sentencing reduction and any time limitations on doing so. See id. at $\S 9.5$. 
analogous ABA Guidelines.

\section{Amsterdam Trial Manual}

Another source of professional standards for defense lawyers in noncapital cases is the trial manual "For the Defense of Criminal Cases," published by the American College of Trial Lawyers, the NLADA, and the American Law Institute-American Bar Association Committee on Continuing Professional Education. ${ }^{128}$ The author of the fifth edition of the manual, Professor Anthony Amsterdam, is a foremost expert in capital and noncapital criminal defense and successfully litigated Furman $v$. Georgia. ${ }^{129}$ The chapters relevant to investigation and sentencing, dating back at least to the 1980s, provide a prescription for competent noncapital sentencing representation and reinforce the conclusion that the investigation and presentation of facts favorable to the defendant, including relevant psychological or psychiatric issues, have long been considered critical to meaningful sentencing representation. ${ }^{130}$

Like the ABA and NLADA guidelines, the trial manual emphasizes the importance of defense sentencing investigation, including interviewing life history witnesses and collecting relevant records. ${ }^{131}$ The manual adds mental health investigation, which the other guidelines do not explicitly include, and it advises defense counsel to consider having the client psychiatrically evaluated -the results of which might support medical rather than punitive treatment and which might prove useful in mitigation. ${ }^{132}$ A comprehensive social history along with corroborating documents undergird any effective mental health evaluation, and that investigation is an indispensable part of developing an accurate and convincing set of conclusions and recommendations concerning a criminal client's mental health history and route to rehabilitation. ${ }^{133}$ The manual suggests that trial counsel take the following actions: provide information to the probation officer preparing the sentencing report and recommendation; and work with the client's employer and family to stabilize the client's life and to make a sentencing plan that maximizes the chances of an outcome

128. AMSTERDAM, supra note 117.

129. See Jeffrey Toobin, Comeback, THE NEw Yorker (Mar. 26, 2007), http://www.newyorker.com/talk/2007/03/26/070326ta_talk_toobin.

130. For a history of the Trial Manual's development and editions, see AMSTERDAM, supra note 117, at vii-ix.

131. AMSTERDAM, supra note 117 , at 181-84, 186-90.

132. Id. at 196. This is particularly salient given that the Bureau of Justice Statistics has concluded that approximately $60 \%$ of prisoners in state prisons and $40 \%$ of prisoners in local jails suffer from mental illness. See Doris J. James \& James E. Glaze, Mental Health Problems of Prison and Jail Inmates (2005), available at http://www.bjs.gov/content/pub/pdf/mhppji.pdf.

133. Richard G. Dudley, Jr. \& Pamela Blume Leonard, Getting It Right: Life History Investigation as the Foundation for a Reliable Mental Health Assessment, 36 HOFSTRA L. REV. 964, 974-75 (2008) ("As a general rule, it is never appropriate to expect a mental health expert to deliver a comprehensive mental health assessment of the client until the life history investigation is complete."). 
short of incarceration ${ }^{134}$-including recommendations for community resources that can help "lend specialized assistance to a probationary regimen." 135 The manual recommends that counsel litigate for disclosure of the presentence investigation report in jurisdictions where it is not disclosed to the defense. ${ }^{136}$ Furthermore, the manual provides more detail than the ABA or NLADA Guidelines about counsel's duty to ensure the accuracy of the client's prior criminal history, requiring, for example, that counsel let the record reflect favorable dispositions of arrests and commitments listed in law enforcement "rap sheets." 137 At the sentencing hearing, the defense should present evidence including witness testimony, affidavits, or letters. ${ }^{138}$ Finally, defense counsel should make an argument on sentencing, the focus of which is individualized sentencing with an emphasis on rehabilitation over retribution. ${ }^{139}$

\section{E. Implications of Noncapital Sentencing Professional Practice Guidelines}

The ABA, NLADA, and Amsterdam standards together establish that effective noncapital sentencing advocacy requires, at a minimum, independent investigation of a client's background, mental health, conditions that might benefit from treatment or social service intervention, and potential for rehabilitation. They require defense lawyers to provide helpful information to the agency preparing the presentence investigation (PSI) report, substantiate its contents, challenge any inaccuracies, and know the relevant sentencing law and procedure. Finally, defense lawyers must be prepared to present and argue in support of any information that may ameliorate the client's sentence.

Notwithstanding these professional standards, mitigation in capital

134. AMSTERDAM, supra note 117, at 286-87.

135. Id. at 291.

136. Id. at 288-89. Here, the manual expressly employs the reasoning from the capital case Gardner v. Florida, 430 U.S. 349 (1977)-wherein the Supreme Court struck down a death sentence as unconstitutional because it was issued based on materials provided to the sentencing judge but not to the defense-to argue for disclosure of PSI reports in noncapital sentencing proceedings. See AMSTERDAM, supra note 117, at 289 ("[A]lthough . . . Gardner is, by its terms, applicable only to death cases, much of the reasoning ... would support a Due Process requirement of PSI reports to the defense in noncapital cases as well.").

137. See AMSTERDAM, supra note 117 , at $297-99$; id. at 298 (noting that clarification is important because "[o]ccasionally a half dozen entries that make the defendant look like Jack the Ripper may be only several stages in the processing of a single criminal charge"); $c f$. NLADA Guidelines, supra note 121, at $\S 8.6(a)(4)$ (using general terms to refer to defense counsel's duty to provide "information favorable to the defendant concerning ... the offense, mitigating factors and relative culpability, prior offenses").

138. AMSTERDAM, supra note 117 , at 301-02.

139. Id. at 302 (noting that the focus "must be on the defendant as a person: his or her good record, lack of violence, and the other factors that make the defendant nondangerous if released; the pressures of the moment that led the defendant to commit this crime and will not recur; the needs for the defendant in the community (to support his or her family, to eam money to make restitution to the complainant); and the greater rehabilitative potential of the favorable disposition counsel urges than of any harsher one"). 
cases is still generally far more developed and robust than it is in noncapital cases. The noncapital guidelines and practice norms certainly provide wide latitude and broad prescriptions for the development, presentation, and consideration of a variety of factors in support of merciful individualized sentencing. However, everyday noncapital defense sentencing practice does not yet reflect the lesson of capital sentencing that presentation of circumstances that have affected the client's understanding and behavior is crucial to a fair assessment of his blameworthiness and to the imposition of a proportional and just sentence.

\section{F. The Relevance of Mitigating Factors To Noncapital Sentencing}

Although the very same circumstances that impact consideration of a capital offender's moral culpability are prevalent among defendants and prisoners implicated in less serious crimes, as discussed infra the Eighth Amendment "death is different" doctrine has definitively distinguished capital from noncapital sentencing. ${ }^{140}$ That distinction has obscured the impact of circumstances such as poverty, trauma, mental illness, intellectual disability, and other unquantifiable and idiosyncratic vulnerabilities in routine criminal cases. Decades of determinate and Guidelines-based sentencing have also discouraged presentation of social history factors deemed irrelevant to the sentencing grids. As described in the next section, institutional and legal hurdles to investigation and consideration of mitigation in noncapital cases certainly remain, but sentencers will continue to lack a meaningful opportunity to consider the relevance of mitigating factors unless noncapital defense lawyers uncover them, corroborate them, and explain their impact on clients' lives. Only after defense lawyers insist on mitigation's consideration will courts routinely begin to accept its salience to any just sentencing.

Comprehensive noncapital mitigation presentations will benefit individual defendants by providing a basis both for a fair sentence and for a meaningful road to rehabilitation and redemption. As in capital cases, development of more probing noncapital mitigation, primarily social histories, will present a more systemic opportunity to "provide a framework for comprehending a single, violent social history, and serve as the basis for the development of a responsible social policy of violence prevention in lieu [of] ... mindless punitiveness . ..."141 Because capital cases necessarily begin with homicides, much capital mitigation helps to explain the genesis of the violence. It follows, however, that some of the same psychological and public health ${ }^{142}$ factors that correlate with violence lead

140. See discussion infra Part V.C.

141. Haney, Social Context, supra note 5, at 562. Professor Haney also describes the destabilizing consequences of poverty, including the chaos occasioned by frequent moves and new schools. Id. at 567 .

142. For example, lead exposure has been linked to a myriad of health problems and rising crime rates. Kevin Drum, America's Real Criminal Element: Lead, MOTHER JONES, Jan./Feb. 2013, available 
others to numb themselves through drug use. ${ }^{143}$ It also follows that poverty ${ }^{144}$ correlates with violent crime and some theft (other than most white collar embezzlement). ${ }^{145}$

\section{Poverty and Trauma}

Two of the most prominent features of capital mitigation are poverty and trauma, including parental abuse and neglect. ${ }^{146}$ Poverty's impact is unmistakably widespread and, though it defies generalization, its psychological and behavioral consequences among some capital defendants include: endemic despair, frustration, undersocialization of children, interference with nurturant parenting, and, in some instances, aggression leading to violence. ${ }^{147}$ There is every reason to expect that poverty has the same psychological effects on people who happen to commit less serious offenses. Yet, unlike in capital cases, in noncapital cases there is no imperative for a sentencer to consider the consequences of poverty on the defendant's moral culpability or for a defense lawyer to present it in mitigation.

The same can be said of trauma, including childhood abuse and neglect ${ }^{148}$ - factors nearly ubiquitous in capital cases. ${ }^{149}$ The psychological and behavioral results of trauma are, like poverty, complex and varied but include: post-traumatic stress disorder (PTSD), depression, anxiety,

at http://www.motherjones.com/environment/2013/01/lead-crime-link-gasoline.

143. Haney, Social Context, supra note 5, at 585; Wayland, supra note 22, at 942. See also S. Fazel et al., Journal of the AMA (May 20,2009) (schizophrenia study); S. Fazel et al., Archives of Gen. Psychiatry (Sept. 2010) (bipolar study documenting markedly higher rates of crime among people with bipolar disorder or schizophrenia when combined with substance abuse).

144. See Jeremy Kaplan-Lyman, A Punitive Bind: Policing, Poverty, and Neoliberalism in New York City, 15 YALE HUM. RTS. \& DEV. L.J. 177, 185 (2012) (noting the positive correlation between poverty and violent crime); Candace McCoy, From Sociological Trends of 1992 to the Criminal Courts of 2020, 66 S. CAL. L. REV. 1967, 1980 (1993) (suggesting poverty's association with other circumstances, such as unemployment, may "dispose a person to commit crimes").

145. For an exploration of the application of mitigation to noncapital white collar criminal proceedings, see Todd Haugh, Can the CEO Learn from the Condemned? The Application of Capital Mitigation Strategies to White Collar Cases, 62 AM. U. L. REV. 1 (2012). For a more general description of white collar sentencing trends, see, for example, Daniel Richman, Federal White Collar Sentencing in The United States: A Work In Progress, 76 LAW \& CONTEMP. PROB. 53 (2013).

146. See Haney, Social Context, supra note 5, at 561-63 (discussing a social history analysis of capital defendants and the common themes of trauma and poverty).

147. Id. at 565 .

148. Id. at 574-75.

149. See generally Wayland, supra note 22, at 930-31 (noting that "[t]he most common traumatic events experienced by many [capitally charged] clients" include "childhood victimization, physical and sexual assault, [and] severe neglect" which are "rarely isolated occurrences"); Haney, Social Context, supra note 5, at 573 ("[W] hen many of us began doing this work . . looking carefully at the social histories of capital defendants, we were struck, all of us, by the frequency with which our clients were brutalized as children. The patterns were striking, but it took years to carefully document them. Now, there is little question about the causal connections. Study after study has confirmed the cycle of violence ...."). 
psychosis, dissociation, significant impairment, and substance abuse, ${ }^{150}$ which is at the heart of several and various types of criminal cases. ${ }^{151}$ Moreover, the effects of childhood maltreatment "reverberate throughout the life course." 152 This fact is well established and is gaining traction in the popular press, with one conservative commentator writing that schools and health care providers are beginning to look more closely at trauma and poverty as "producing enormous amounts of stress and unregulated behavior, which dulls motivation, undermines self-control and distorts lives." 153

The criminal justice system, along with the health care system, is the institution most likely to document the psychological and behavioral effects of poverty and trauma on adults-yet it requires no accounting of these factors in noncapital cases. When adults who have survived brutal abuse and neglect in childhood or trauma inflicted in adulthood, including in custodial settings, commit noncapital crimes, there is no requirement that sentencers account for the trauma or its psychological or behavioral effects before they fix punishment. Notwithstanding the professional guidelines, there is also no legal requirement that defense lawyers present such evidence of their clients' traumatic histories.

\section{Racial Discrimination}

The effects of racial discrimination constitute another pervasive trauma that is common among those charged with and convicted of crimes. As Professor Haney has eloquently put it: "You must confront the fact that racism, institutional racism, exposes persons of Color to experiences that no one else has in this society, experiences that leave an indelible mark."154 The convergence of racism with other types of maltreatment and poverty is uniquely debilitating. ${ }^{155}$ Racism is also a major contributor to arrests or convictions of "street crimes," which are often the basis of defendants' prior records and increase their punishment liability. ${ }^{156}$ In fact, at least one court

150. Wayland, supra note 22, at 943 .

151. Haney, Social Context, supra note 5, at 584; see also BUREAU OF JUSTICE STATISTICS, DRUGS AND CRIME FACTS, available at, http://bjs.ojp.usdoj.gov/content/dcf/duc.cfm\#drug-related.

152. Debra Umberson et al., Social Relationships and Health Behavior Across Life Course, 36 ANNU. REV. SOCIOL. 139, 139 (2010). The Supreme Court has continued to affirm the principle that youth is particularly mitigating. See Miller v. Alabama, 132 S. Ct. 2455 (2012); Jackson v. Hobbs, 132 S. Ct. 1733 (2012); Graham v. Florida, 560 U.S. 48 (2010); Roper v. Simmons, 543 U.S. 551 (2005). Yet, the impact of youthful trauma is not neatly quarantined to the period before a person tums eighteen, particularly because juvenile status is the paradigmatic "bright line" condition. It is absurd to think that someone who may be eighteen and a half, nineteen, or even in his early twenties is somehow so far removed from events marring his formative development that his background is not relevant to an assessment of his moral culpability.

153. David Brooks, The Psych Approach, N.Y. TMES, Sept. 28, 2012, at A35, available at http://www.nytimes.com/2012/09/28/opinion/brooks-the-psych-approach.html?_r=0.

154. Haney, Social Context, supra note 5, at 582 (emphasis in original).

155. Id. at 580 .

156. Lanni, supra note 103 , at 1786. 
has issued a downward sentencing departure based on criminal history in recognition of the disproportionate arrests of black men for minor traffic violations, which in that case comprised most of the defendant's prior convictions. ${ }^{157}$ Another federal sentencing court considered in remarkable detail the defendants' social histories and the role of racism in trapping some of those defendants in a practically inescapable matrix of deprivation. ${ }^{158}$ These decisions suggest that some courts are open to consideration of racial discrimination as a mitigating factor. Despite the fact that racism is a trauma that diminishes opportunity and increases exposure to punishment, the impact of racism, much less the cumulative effect of racism compounded by multiple trauma and poverty, rarely if ever makes it into a presentence presentation of any kind in a noncapital case. ${ }^{159}$

\section{Intellectual Disability}

Intellectual disability, formerly known as mental retardation, is so central to the evaluation of a capitally charged person's moral culpability that it precludes imposition of the death penalty. ${ }^{160}$ Among the reasons people with intellectual disability should not be sentenced to death are their "diminished capacities to understand and process information, to communicate, to abstract from mistakes and learn from experience, to engage in logical reasoning, to control impulses, and to understand the reactions of others." 161 The intellectually disabled are also more likely to be followers rather than leaders and to act on impulse rather than as the result of premeditation. ${ }^{162}$ Intellectual disability may also interfere with a person's capacity to assist with his defense or to appear remorseful for his crimes. ${ }^{163}$ Each of these characteristics applies with equal force to intellectually disabled people charged with noncapital crimes. ${ }^{164}$ Yet, the Supreme Court has never held that intellectual disability is a relevant noncapital sentencing consideration, leaving it up to individual jurisdictions how they account for intellectual disability at punishment-even when the defendant is facing a sentence as harsh as life without the possibility of parole. ${ }^{165}$

157. United States v. Leviner, 31 F. Supp. 2d 23, 33-34 (1998).

158. United States v. Bannister, 786 F. Supp. 2d 617, 631-33 (2011) (dedicating a portion of the opinion to the "Roots of African American Segregation and Poverty").

159. As with a number of the mitigating circumstances described herein that capital defense lawyers have presented in their cases but noncapital defense lawyers generally have not, evidence of systemic racism has long been used in capital litigation. See Buck v. Thaler, 132 S. Ct. 32 (2011); Snyder v. Louisiana, 552 U.S. 472 (2008); Miller-El v. Dretke, 545 U.S. 231 (2005); McCleskey v. Kemp, 481 U.S. 279 (1987).

160. Atkins v. Virginia, 536 U.S. 304, 306-07, 321 (2002).

161. Id. at 318 .

162. Id.

163. Id. at 320-21.

164. See Barkow, supra note 19 , at 1161 .

165. See id. 
The upshot is that though the very same adverse social forces that characterize the lives of capital defendants riddle the backgrounds of noncapital defendants, aside from recommendations in the professional standards for criminal defense lawyers, there is no doctrinal requirement that defense attorneys present these factors, or that noncapital sentencers be made aware of or take these factors into account before imposing punishment. To be sure, the convergence of factors in any person's life is going to impact her uniquely. ${ }^{166}$ But the hard work of describing the particular mitigating effect of a terrible life history on the person standing accused of an aggravated crime is at the heart of effective capital representation, and it should be at the core of noncapital representation as well. Otherwise, individualized justice will continue to elude most criminal proceedings, and the view that unfettered choice, endemic personal evil, and unmoored "free will" are the reasons people violate the law will continue to unduly influence noncapital sentencing. ${ }^{167}$ Meaningful noncapital mitigation presentations also present affirmative opportunities to treat sentencing hearings as fact-finding tribunals that produce a cumulative record of social histories that can discern patterns to help experts, social service providers, policymakers, and actors in the justice system develop effective treatments for the recurring ills strongly associated with crime. ${ }^{168}$

\section{Positive Sentencing Factors}

One final point on the development of mitigation in noncapital cases: as the professional guidelines and Professor Amsterdam's trial manual reflect, in noncapital sentencing there must be more emphasis on positive factors in the defendant's life, such as educational and employment opportunities, family support, and access to and amenability to rehabilitative services. ${ }^{169}$ This is how it should be if alternatives to longterm incarceration and rehabilitation are primary goals of the justice and penal systems. In order for noncapital defense lawyers to advocate successfully for less punitive sentences and alternatives to lengthy prison terms, they will need to account for both the adverse life circumstances that explain a client's participation in a criminal offense as well as the positive and protective factors in the client's life that will make him a candidate

166. Haney, Social Context, supra note 5, at 602 ("[V]irtually no psychological cause or social influence produces the same effect in everyone.").

167. See id. at 603 .

168. See id. at 606-08. This argument does not account for the fact that plenty of wealthy people break the law privately all the time (e.g., abusing drugs) and are never caught, arrested, or charged, so any conclusions about the roots of criminal behavior will be skewed by arrest and charging patterns. Relatively wealthy law breakers' behavior may not be attributable to poverty, or, if they are white, to racism, but it may be influenced by trauma or other mental illness.

169. See AMSTERDAM, supra note 117, at 196; NLADA Guidelines, supra note 121 , at $\$ 8.2$; $c$. Barkow, supra note 19, at 1201 (suggesting courts use a more restrictive approach, requiring "only mitigating evidence that relates to a defendant's reduced culpability" and not requiring "evidence about a defendant's good moral character or prospects for rehabilitation"). 
worthy of rehabilitation and, even if he is sent to prison, eventual reintegration into the free world. In a noncapital case, it will not be enough, as it might be in some capital cases, to explain the roots of someone's lawbreaking behavior. A good sentencing advocate must also describe how a person will live, and what resources the client needs and will have available if he is given a chance outside prison. This is particularly true because circumstances such as mental illness and addiction may inspire fear in the sentencer that if the defendant is not incarcerated he will be a danger to others or to himself. ${ }^{170}$ In capital cases, by contrast, there is usually no possibility that the convicted person will be released, so the consideration is only whether he will be a danger in prison. Thus, in noncapital cases the careful presentation of protective factors that will buffer the adverse consequences of the defendant's troubled life history is crucial to guarding against the conclusion that mitigation is double edged.

Notwithstanding the reasons outlined here-those grounded in professional duty, those supporting individualized sentencing, and those urging an opportunity to learn more about the true causes and possible means of reducing crime-powerful institutional hurdles present challenges to widespread adoption of the worthy practice of investigating, presenting, and considering social history mitigation in noncapital sentencing. The next section explores some of those challenges.

\section{Institutional Hurdles to More Robust Noncapital Mitigation}

Several institutional and legal hurdles hinder more robust noncapital mitigation. The sheer variety and volume of possible cases and lack of indigent defense resources (both time and money), and the fact that most noncapital cases are resolved by pleas preclude mitigation efforts. Further, there are challenges in applying the "death is different" paradigm that has been the basis of the Eighth Amendment requirement of individualized capital sentencing and related challenges in applying it to noncapital sentences, particularly in jurisdictions with mandatory sentencing and where judges, not juries, impose punishment.

\section{A. Variety and Volume of Noncapital Cases}

Noncapital criminal cases run the gamut from petty theft to noncapital murder, unlike in capital cases where a homicide with some aggravating feature forms the basis of the capital charge. It is therefore almost impossible to enforce a uniform set of actions that defense lawyers

170. For example, evidence of brain damage might be double-edged in a noncapital case. When presented effectively in a capital case, brain damage can be quite powerful mitigation. See Porter v. McCollum, 558 U.S. 30, 42 (2009). In a noncapital case, however, where the sentencer will be concerned about the permanence or intractability of a defendant's proclivity for instability, unpredictable behavior, or violence, emphasis on brain damage may not be ideal mitigation if the defense's goal is reduced incarceration time. 
must take in every criminal case in order to ensure effective sentencing advocacy.

As the noncapital guidelines establish, the following are basic tools that should apply in every case, and this list is by no means exhaustive: independent defense investigation of the circumstances of the offense; defense verification or challenge of items in any agency-prepared presentence report; defense investigation of a client's prior record, including mitigating factors relevant to prior offenses and clarification if certain charges never resulted in convictions; defense investigation of the client's social history-including poverty, living conditions, dependent relatives, employment history and opportunity, history of mental illness or substance addiction, cognitive ability or intellectual deficit, trauma history; investigation of community resources that are viable alternatives to incarceration or a means of improving prospects of rehabilitation even if prison is unavoidable; and preparation of a defense sentencing plan and argument to be presented orally or in writing, with supporting evidence, to the probation agency, if appropriate, and the sentencing judge. ${ }^{171}$

Each case will warrant its own approach, tailored to the individual client and the seriousness of the charged offense. The more serious offenses may necessitate hiring a defense sentencing specialist akin to a mitigation specialist in capital cases. ${ }^{172}$ Minor offenses may call for a simple explanation of the circumstances leading to the client's criminal involvement and a proposal for social work or mental health intervention, along with some form of appropriate restitution instead of a lengthy incarceration. The range of possibilities for sound sentencing advocacy will vary along a continuum according to the seriousness of the offense. This is not to suggest, however, that consideration of a client's background should be taken less seriously in cases involving minor offenses. To the contrary, if a defense team identifies a client's vulnerabilities and areas that would benefit from available support and can advocate successfully for programs that will divert him from more serious criminal involvement, then defense counsel will have succeeded in using mitigation exactly as it is intended to work. $^{173}$

The caseloads facing most defense lawyers, especially public

171. See, e.g., Jenny Roberts, Why Misdemeanors Matter: Defining Effective Advocacy in the Lower Criminal Courts, 45 U.C. DAVIS L. REV. 277, 317 (2011) (discussing defense counsel's "duty to investigate evidence relevant to mitigation of the sentence"). See also State v. Fuerst, 512 N.W.2d 243, 246 (Wis. Ct. App. 1994) (noting that a defendant's "personal and social history is important to" sentencing consideration); Byrne Hessick \& F. Andrew Hessick, Recognizing Constitutional Rights at Sentencing, 99 CALIF. L. REV. 47, 52 (2011) (stating that sentences can vary "based on the particular facts and circumstances surrounding the crime, such as harm to the victim or the defendant's motive").

172. The sentencing specialist would assist in interviewing witnesses and gathering documents to build the social history, facilitate work with any experts who can help explain the impact of the client's background on his behavior, particularly leading up to the offense, and assist in drafting the defense presentence report and proposed plan for treatment and rehabilitation or for appropriate therapeutic support while the client is in custody.

173. See, e.g., Roberts, supra note 171 , at 317 . 
defenders, present a more difficult institutional obstacle to routine comprehensive defense sentencing investigation. In many jurisdictions, public defender offices bear dockets of 100 or more cases per attorney, preventing these attorneys from performing basic tasks required by the Sixth Amendment, such as staying in touch with their clients or filing motions in their cases. ${ }^{174}$ In addition, since most noncapital prosecutions proceed much more quickly than capital prosecutions, the difficulties of building trust and rapport with witnesses and gathering records in enough time to meaningfully investigate mitigation are exacerbated in the noncapital context. Money is also an issue, especially for court-appointed lawyers who work in private practice rather than in institutional defender organizations with staff investigators, social workers, and budgets for mitigation specialists and other experts. ${ }^{175}$ It is therefore difficult to imagine overburdened public defenders having the time or resources to provide comprehensive mitigation investigation in each of their cases on a regular basis. ${ }^{176}$

Plenty has been written proposing strategies to reduce public defender caseloads and allow for more effective indigent criminal representation, and those recommendations need not be repeated here. ${ }^{177}$ The proposal here, instead, is that public defender offices and other attorneys with available resources take the lead in devoting time and funding to meaningful investigation into mitigating circumstances relevant to their client's blameworthiness and capacity for rehabilitation. Some dedicated defenders and innovative offices already do so. ${ }^{178}$ Those who do

174. See Norman Lefstein, Securing Reasonable Caseloads: Ethics and law In PUblic DEFENSE 12-13 (Joel Schumm ed. 2011); see also Hessick, supra note 26, at 1113 (citing the "overwhelmingly large number of noncapital convictions and sentencings" that occur annually).

175. See James M. Anderson \& Paul Heaton, Measuring the Effect of Defense Counsel on Homicide Case Outcomes, NAT'L INST. OF JUST. Dec. 2012, at 3, 36-37, available at https://www.ncjrs.gov/pdffilesl/nij/grants/241158.pdf (reporting that in Philadelphia homicide cases, defendants with lawyers from the public defender's office, as opposed to appointed private counsel, had more favorable case outcomes, including reduction of life sentencing by $64 \%$ and reduction of overall expected prison time by $24 \%$, and citing the public defender office's ability to hire experts as one reason for the disparity).

176. Resources are a very difficult implication in capital cases as well, and many capital defendants face trial and habeas proceedings with fewer resources than necessary for a meaningful defense. Even in Rompilla-one of the Supreme Court's bedrock capital ineffective assistance casesthe dissent pointed to the difficulty of implementing the majority's holding given the scarcity of resources for capital defenders. See Rompilla v. Beard, 545 U.S. 374, 403 (Kennedy, J., dissenting) (noting that the public defender's office that represented Rompilla at trial had two investigators for 2,000 cases).

177. See, e.g., LEFSTEIN, supra note 174; THE CONSTITUTION PROJECT, JUSTICE DENIED: AMERICA'S CONTINUING NEGLECT OF OUR CONSTITUTIONAL RIGHT TO COUNSEL 7-9 (2009), $\mathrm{http}: / / \mathrm{www} . c 0 n s t i t u t i o n p r o j e c t . o r g / p d f / 139 . p d f$ (noting the impediments to effective defense systems and reforms in the system); NAT'L ASSOC. OF CRIMINAL DEFENSE LAWYERS, MINOR CRIME, MASSIVE WASTE: THE TERRIBLE TOLL OF AMERICA'S MisdemeanOR COURTS (2009), http://www.opensocietyfoundations.org/sites/default/files/misdemeanor_20090401.pdf (explaining factors rendering attorneys incapable of providing adequate legal representation to minors and recommendations to improve such legal representation).

178. The Neighborhood Defender Service of Harlem and the Bronx Defenders in New York City 
are advancing a necessary movement toward more meaningful individualized sentencing, a reduction in overly harsh punishment, and a look into the root causes of various crimes that may provide an opportunity for development of more effective crime policies. Neighborhood-based public defender agencies are especially well-situated to provide comprehensive mitigation more efficiently than other indigent defense providers because their locus in a particular community and an intimate knowledge of a concentrated client population lowers the cost of aggregating information about mitigating circumstances - such as arrest patterns in over-policed areas, knowledge of particularly violence-plagued housing complexes, shortages of mental health care resources, and so on. ${ }^{179}$ These neighborhood defenders might therefore be best positioned to provide wholesale mitigation data to courts at the lowest cost, after developing the data in individual clients' cases.

Law school clinics are another resource. ${ }^{180}$ Clinics may partner with institutional defenders to expand defender offices' capacity to investigate and present mitigation in sentencing hearings. Clinics may also represent clients on their own and develop improved sentencing practices that they might share through the development of practice manuals and trainings made available to attorneys and investigators in their communities. Partnerships with law schools, social work schools, and schools of public health, for example, could augment defenders' resources and utilize research and scholarship to develop data that might help explain whether and why certain life circumstances are correlated with particular types of criminal involvement.

Foundations and public funding sources dedicated to improving justice systems should make resources available that will foster such partnerships and allow public defender agencies to reduce their caseloads, provide attorney and investigator training, and hire mitigation specialists that will enhance their capacity for comprehensive sentencing advocacy.

None of these are perfect solutions, but they are steps toward normalizing and making more widespread the expectation that mitigation is a central, rather than marginal, part of competent noncapital defense sentencing advocacy.

are good examples of offices that integrate social workers into their criminal defense teams to work toward the best possible sentencing dispositions for clients. NEIGHBORHOOD DEFENDER SERVICE OF HARLEM, http://www.ndsny.org/programs/criminal-defense.html (last visited Oct. 20, 2013); BRONX DEFENDERS, http://www.bronxdefenders.org/our-work/social-work (last visited Oct. 20, 2013).

179. The Four Pillars of Holistic Defense, THE BRONX DEFENDERS (Nov. 15, 2010), http://www.bronxdefenders.org/the-four-pillars-of-holistic-defense/.

180. Stanford Law School's Three Strikes Clinic has provided effective mitigation representation in the cases of clients who have been life-sentenced based on sometimes low-level offenses that counted as their "third strikes." Brent Staples, California Horror Stories and the 3-Strikes Law, N.Y. TIMES, Nov. 25, 2012, at SR10, available at http:/www.nytimes.com/2012/11/25/opinion/sunday/california-horror-stories-and-the-3-strikeslaw.html?_r=0. 


\section{B. Prevalence of Plea Bargaining}

The vast majority of noncapital criminal cases are resolved by pleas. $^{181}$ In the 2012 term, the Supreme Court in Missouri v. Frye ${ }^{182}$ and Lafler v. Cooper ${ }^{183}$ delineated the considerations for determining when a lawyer's performance is constitutionally ineffective when a client is convicted at trial and the resulting sentence is substantially longer than the sentence that would have resulted had the client been properly advised of an available plea. ${ }^{184}$ In doing so, the Supreme Court recognized, as lower courts have for some time, ${ }^{185}$ that the prevalence of agreed dispositions in criminal cases necessitates a standard for the effective assistance of defense lawyers not just at trial but also during plea bargaining, which has become "central to the administration of the criminal justice system." 186 In fact, one federal appellate judge has observed that "virtually all defendants plead guilty, usually in return for some sentencing concession as compared with the 'going rate' after trial." 187 That "going rate" is inflated by design in order to incentivize more defendants to choose pleas, ${ }^{188}$ and a defendant's principal incentive to plead guilty is to leverage the best possible sentence, which is usually better than the sentence that could result from a trial conviction. ${ }^{189}$ In the federal system, the Sentencing Guidelines explicitly reward cooperation by offering "acceptance of responsibility" and "substantial assistance" credits that reduce the defendant's sentencing liability if he provides information helpful to prosecutors about other prospective defendants. ${ }^{190}$ Prosecutors hold nearly unilateral discretion ${ }^{191}$ in choosing charges, and that choice in turn determines minimum sentences. ${ }^{192}$

181. See Missouri v. Frye, 132 S. Ct. 1399, 1407 (2012) (noting that "plea bargains have become . . central to the administration of the criminal justice system"); Lafler v. Cooper, 132 S.Ct. 1376, 1388 (2012) (noting that $97 \%$ of federal convictions and $94 \%$ of state convictions result in guilty pleas); see also Hessick, supra note 26, at $1070 \mathrm{n} .5$ (citations omitted) (citing federal and state rates on plea bargaining). For a discussion of the duty of counsel to negotiate pleas in capital cases, see Russell Stetler, Commentary on Counsel's Duty to Seek and Negotiate a Disposition in Capital Cases, 31 HOFSTRA L. REV. 1157 (2003).

182. 132 S. Ct. 1399 (2012)

183. 132 S. Ct. $1376(2012)$.

184. Frye, 132 S. Ct. at 1410-11; Lafler, 132 S. Ct. at 1386.

185. Gerald E. Lynch, Frye and Lafler: No Big Deal, 122 YALE L.J. ONLINE 39, 42 (2012).

186. Frye, 132 S. Ct. at 1407; see also Lafler, $132 \mathrm{~S}$. Ct. at 1388.

187. Lynch, supra note 185 , at 40.

188. Id. at 41 .

189. Id.

190. U.S. SENTENCING GUIDELINES MANUAL § 3E1.1 (2011); 18 U.S.C. $\S 3553(\mathrm{e})$ (2013); see also Stephanos Bibas, Plea Bargaining Outside the Shadow of Trial, 117 HARV. L. REV. 2463, 2485-86 (2004) (noting that "[t]he Federal Sentencing Guidelines have put a huge premium on another pleabargaining technique: cooperating with the government").

191. Angela J. Davis, The American Prosecutor: Power, Discretion, and Misconduct, 23 CRIM JusT. 24, 25-26 (2008-2009).

192. Daniel Richman, Federal Sentencing in 2007: The Supreme Court Holds-The Center Doesn't, 117 YaLE L.J. 1374, 1386 (2008). 
Prosecutors then decide how much sentencing credit to recommend. ${ }^{193}$

The deeply entrenched dependence on plea bargaining, which is premised on bartering reductions of "going" sentencing rates, to resolve the vast majority of cases poses an essential challenge for the prospect of individualized punishment. ${ }^{194}$ It may be, in fact, that making mitigation central to noncapital sentencing requires an upending of the current approach to plea bargaining and reimagining prosecutorial discretion altogether ${ }^{195}$ _ but that revolution does not appear in the immediate offing, which is the reason the focus of this paper is on the means immediately available to defense lawyers to erode barriers to more mitigation-centered noncapital sentencing.

The way plea bargaining works now--including prosecutors' nearly unfettered power in charging, negotiating, and recommending sentences ${ }^{196}$ - only underscores the importance of mitigation in noncapital pled cases, where the audience for mitigation needs to be as much the prosecutor as it does the sentencing court. ${ }^{197}$ In pled cases, the timing of investigating and presenting mitigation may be compressed as compared to tried cases, particularly where post-trial sentencing takes place at a hearing weeks or months after conviction. ${ }^{198}$ It may mean that the social history investigation and the involvement of any experts who will help counsel determine the impact of available mitigation must take place prior to the plea negotiations, and ideally before a prosecutor decides which charges to bring. As noted, once a particular charge attaches, there is enormous incentive for prosecutors to recommend a sentence within a uniform range. Regardless of its timing, a defense mitigation presentation should play a central role in the negotiation influencing a prosecutor's decision whether to settle a case and by what terms. The practice guidelines for defense counsel in noncapital cases buttress the point and cast it in terms of professional

193. Michael A. Simons, Prosecutorial Discretion in the Shadow of Advisory Guidelines and Mandatory Minimums, 19 TEMP. POL. \& CIV. RTS. L. REV. 377, 380 (2010).

194. See Nancy Gertner, From "Rites" to "Rights": The Decline of the Criminal Jury Trial, 24 YALE J.L. \& HUMAN. 433, 436 (2012) (recognizing that plea bargaining has caused "many aspects of the criminal justice system" to suffer, including "meaningful discovery" and "the jury trial").

195. See, e.g., Simons, supra note 193 (suggesting prosecutors develop policies, in the postBooker era, which ensure that prosecutorial discretion is exercised "in ways that are fair, rational, and consistently based on the principles of punishment").

196. See William J. Stuntz, Plea Bargaining and Criminal Law's Disappearing Shadow, 117 HARV. L. REV. 2548, 2558 (2004) (stating that prosecutors possess much more power and opportunity to dictate outcomes of plea bargaining than defense attomeys); see also AMSTERDAM, supra note 117, at 353-54. (describing the kinds of sentencing recommendations prosecutors can make and of conditional versus unconditional pleas); see also Barkow, supra note 19, at 1153 (acknowledging that the structure of federal and state criminal codes add to "the likelihood of discriminatory application of sentencing in noncapital cases").

197. One federal public defender I spoke with went as far as saying that given how seldom federal cases proceed to trial, he and his colleagues should be considered "mitigation specialists" themselves, because most of their advocacy goes to leniency after a plea.

198. Gertner, supra note 194, at 436. 
responsibility. ${ }^{199}$ In fact, the Supreme Court has said explicitly that in pled cases, any dereliction of this professional duty that results in an increased prison sentence for a client has constitutional implications. ${ }^{200}$

Moreover, to the extent that prosecutors are repeat actors in criminal cases in a given jurisdiction and feel compelled to "treat like cases alike" based on charges or alleged conduct, zealous advocacy requires defense lawyers set their clients apart from others accused of similar offenses by presenting evidence of the client's unique vulnerabilities, comparatively diminished relative culpability, prospects for rehabilitation or a productive life outside of prison, and any other mitigating factors. This lies at the heart of the duty to present an individualized sentencing portrait to the person with the most power over the disposition, which in pled cases is, de facto, the prosecutor.

The challenge will be for over-worked and under-funded defense lawyers to adopt these practices in the cases where their clients intend to plead. Aside from defense resource constraints, changing prevailing plea bargaining practices and expectations among the defense bar, prosecutors, and judges in any given jurisdiction will require a number of fundamental changes beyond the scope of this paper, beginning with a significant reduction in cases prosecuted. Still, a concerted defense effort to begin raising standards and laying a course for more rigorous mitigation investigation in noncapital cases resolved by plea is a critical starting point for working mitigation into the largest category of criminal cases. ${ }^{201}$

\section{Death Is Different}

The most fundamental doctrinal impediment to more routine, rigorous mitigation in noncapital sentencing is the Supreme Court's as-yet unwavering position that "death is different." ${ }^{202}$ There is no constitutional

199. NLADA Guidelines, supra note 121, at $\S \S 8.1(\mathrm{a})(1), 8.2(\mathrm{c})(1)$; $c$. DEFENSE FUNCTION STANDARDS, supra note 107, at $\S 4-6.2$ (where the ABA Guidelines are again far less specific than the corresponding NLADA Guidelines).

200. See Lafler v. Cooper, 132 S. Ct. 1376, 1386 (2012) ("[T]neffective assistance of counsel during a sentencing hearing can result in Strickland prejudice because any amount of additional jail time has Sixth Amendment significance.") (internal quotation marks and punctuation omitted); see also Glover v. United States, 531 U.S. 198, 203-204 (2001) ("[O]ur jurisprudence suggests that any amount of actual jail time has Sixth Amendment significance.").

201. Raising the bar of criminal practice can be brought about either through the work of trial attorneys who adopt more rigorous practices and turn those practices into the prevailing norm, or by habeas challenges to a particular lawyer's performance which a court may use as an occasion to clarify the baseline for competent practice. Habeas challenges to ineffective assistance of counsel during plea bargaining will be difficult to prove because of the off-the-record nature of plea negotiations and the paucity of appeals following voluntarily accepted pleas. For that reason, as well as the difficulty of proving prejudice in pled cases, some have argued that even if the Supreme Court were to recognize heightened professional norms applicable to noncapital sentencing, they would not benefit most noncapital defendants, particularly those who choose to plead. See Steiker \& Steiker, Opening $a$ Window, supra note 11, at 199-200.

202. Jeffrey Abramson, Death-Is-Different Jurisprudence and the Role of the Capital Jury, 2 OHIO ST. J. CRIM. L. 117, 117 n.1 (2004) (chronologically tracking development of the Supreme Court's 
right to individualized noncapital sentencing, and therefore no corresponding requirement that the defendant's life circumstances be investigated, presented, or considered before punishment is handed down in a noncapital case. ${ }^{203}$ As Professor Rachel Barkow has written, however, "The Court's decisions prohibiting arbitrariness, requiring individualization, and ensuring proportionality are grounded in the Eighth Amendment, which prohibits the infliction of "cruel and unusual punishments.' There is no hint in the text itself that these terms should mean one thing in capital cases and another in noncapital cases." 204 The death penalty certainly benights the rest of our criminal justice system. Yet, as long as it remains available, it is different in its irreversibility and finality; ${ }^{205}$ every safeguard against its infliction is justified and many should be expanded. ${ }^{206}$ However, the fact remains that the vast majority of criminal defendants are in prison for noncapital crimes, and many are facing staggering prison terms. As long as there is no Eighth Amendment requirement of individualized noncapital sentencing, challenges to noncapital sentences' proportionality are unlikely to succeed, and there is no basis for a finding of Sixth Amendment Strickland prejudice when a trial lawyer fails to investigate or present mitigation at noncapital sentencing.

Though mitigation is crucial to any meaningful shift toward individualized sentencing-because it will require courts to slow down and learn about the people they are punishing, shed light on the root causes of crime, ideally influence a reconsideration of lengthy incarceration in many individual cases and, in the long-term, across cases-doctrinally there is no Sixth or Eighth Amendment requirement that lawyers present or that courts consider noncapital mitigation. Moreover, the different structures of capital and noncapital sentencing proceedings make it such that most noncapital habeas claims challenging counsel's effectiveness refer to guilt rather than penalty. In addition, though the Supreme Court has held that there is a

"death-is-different" doctrine).

203. See Harmelin v. Michigan, S01 U.S. 956, 994-95 (1991).

204. Barkow, supra note 19, at 1163. Also see Haney, Social Context, supra note 5, at 603-04 for the following support:

Despite the tension that social history evidence creates in the operation of the system of death sentencing, the opportunity to find and present such evidence is now constitutionally mandated. The principle that a sentencer's 'possession of the fullest information possible concerning the defendant's life ...' is essential to the selection of the appropriate penalty predates the modern era of capital jurisprudence and has never been restricted exclusively to death penalty cases. It was embraced and reaffirmed both before and after Lockett, the case generally identified as having given rise to this requirement in contemporary capital litigation.

205. But see Barkow, supra note 19, at 1167-74 (arguing that death is not uniquely severe or final); Id. at 1201 (advocating for limiting the types of mitigation that may be presented in capital cases as one strategy for bringing uniformity to noncapital and capital sentencing). This is a position I cannot agree with given the qualitative difference between state-imposed execution and a long prison term, which undoubtedly is a taking of a different kind, but not one that extinguishes a life. In prison, there is always a chance of redemption, rehabilitation, or release.

206. Steiker \& Steiker, Opening a Window, supra note 11, at 157-59. 
single Sixth Amendment standard for judging attorney effectiveness, it has enforced that standard more robustly in capital than in noncapital cases. ${ }^{207}$ The structural differences between capital and noncapital sentencing make it difficult to apply the Supreme Court's capital ineffectiveness doctrine squarely to noncapital sentencing. ${ }^{208}$

First, capital defendants are nearly always sentenced by juries rather than judges. ${ }^{209}$ Although there are jurisdictions with noncapital jury sentencing, most noncapital sentences are imposed by judges. ${ }^{210}$ Much has been written about the different approaches to sentencing taken by juries as compared to judges. ${ }^{211}$ Judges are more likely to want to treat like cases alike and maintain some semblance of uniformity in sentencing. They are also professional sentencers, as opposed to juries who are generally making a single sentencing decision and are therefore less likely than judges to suffer from "compassion fatigue" after hearing day in and day out tales of poverty, trauma, and mental illness. ${ }^{212}$ However, more comprehensive mitigation at noncapital sentencing may upend the idea that judges are bound to treat cases that may appear at first blush to be alike when the focus is only on the offense. As for compassion fatigue, the precise challenge is to present facts that persuade the sentencer that no matter how many stories he has heard before, this defendant is both worthy of leniency and capable of redemption. If capital litigation has demonstrated anything, it is that mitigation, even in cases involving the most serious crimes, has the power to convince the sentencing court that viewing a defendant's actions during a particular criminal offense in isolation and at face value is not a just basis for fixing punishment. ${ }^{213}$ Cases that may appear to be alike may not be alike at all, and the defense lawyer's role is to set her client apart and provide a basis for mercy before a court accustomed to routinely handing down prison terms without much information about the people being sent to

207. As discussed above, nearly all the Supreme Court precedent on the effective assistance of counsel during sentencing has been decided in capital cases and depends on the bifurcated capital proceedings in which sentencing is its own phase of trial, presided over by a jury required to consider mitigating evidence. See Hessick, supra note 26, at 1071, 1071 n.8 (citing Eva S. Nilsen, Decency, Dignity and Desert: Restoring Ideals of Human Punishment to Constitutional Discourse, 41 U.C. DAVIS L. REV. 111, 152 (2007) (characterizing the Supreme Court's noncapital sentencing jurisprudence as a "virtual blank check" to legislatures)). See also Steiker \& Steiker, Opening a Window, supra note 11, at 190-91.

208. See Steiker \& Steiker, supra note 11, at 198-99.

209. See Douglas A. Berman, Examining the Blakely Earthquake and Its Aftershocks, 16 FED. SENT'G REP. 307 (2004).

210. Barkow, supra note 19, at 1153; Hessick, supra note 26, at 1095.

211. See, e.g., Nancy King, How Different Is Death? Jury Sentencing In Capital and NonCapital Cases Compared, 2 OHIo ST. J. of CRIM. L. 195 (2004); Morris B. Hoffman, The Case For Jury Sentencing, 52 DUKE L.J. 951 (2003); Lanni, supra note 103.

212. See Dianne Molvig, The Toll of Trauma, 84-DEC. WISC. LAw. 4, 8 (2011) (stating that judges are among those affected by compassion fatigue).

213. See Lanni, supra note 103, at 1778 (contrasting "just deserts" sentencing, which focuses on the nature of the crime, with rehabilitative sentencing, which looks more at the individual characteristics of the offender). 
prison. ${ }^{214}$

For state cases, the role of elected judges complicates the picture. The perception of judicial leniency has cost some judges their seats and electoral pressures therefore promote a tendency to be "tough on crime" in all but the most unusual cases. ${ }^{215}$ There is no easy answer to this other than to use zealous defense sentencing practices to shift both the expectations of courts and the punishment baselines over time so that the touchstone of harshness or leniency becomes less draconian. Moreover, studies have shown that lay people are actually less punitive than judges when presented with detailed information about particular people convicted of crimes. ${ }^{216}$ If the discourse around crime moves from the offense to the provision of more data about the person accused or convicted of the offense, the seemingly bottomless appetite for harsh punishment may abate.

Judicial sentencing in noncapital cases also has implications for appellate review or reconsideration of sentences. Unlike in capital cases, a court examining a Sixth Amendment challenge to counsel's performance in a noncapital case will not determine the probability that a juror would have decided differently in light of the new evidence, which is a question requiring judges to substitute their own judgment for that of a reasonable juror. Rather, challenges to defense counsel's performance during judgeimposed sentencing will require judges to consider whether a reasonable judge would have found a particular set of mitigating circumstances persuasive enough to have imposed a less punitive sentence. ${ }^{217}$ That may pose a formidable obstacle to habeas challenges to noncapital sentences for some time, particularly when federal courts are reviewing state court judgments. ${ }^{218}$ However, this also presents another opportunity to educate

214. A United States Sentencing Commission survey of federal judges reveals that although some judges believe that factors such as "mental condition" and "disadvantaged upbringing" are relevant to sentencing within the guidelines-and, in some instances, to whether to grant a downward variance from the guidelines range - these factors are less relevant in most judges' view than is evidence of rehabilitation. See U.S. SENT'G COMM'N, RESULTS OF SURVEY OF UNITED STATES DISTRICT JUDGES $\begin{array}{lllllll}\text { JANUARY } & 2010 & \text { THROUGH } & \text { MARCH } & 2010, & 18 & \text { (2010), }\end{array}$ http://www.ussc.gov/Research_and_Statistics/Research_Projects/Surveys/20100608_Judge_Survey.pdf. This bolsters the conclusion that more must be done to expose judges to life history mitigation and to persuade them of its salience. Of course someone's mental condition or social disadvantage will affect his ability to improve his life and will define the starting point from which he must travel before he is considered truly rehabilitated. In other words, it is impossible to evaluate prospects for rehabilitation apart from a defendant's social context.

215. See, e.g., Lynn Adelman \& Jon Deitrich, Why Habeas Review of State Court Convictions Is More Important than Ever, 24 FED. SENT'G REP. 4 (2012) (discussing how state judicial elections influence decisions in criminal cases); see also Haney, War on Prisoners, supra note 23, at 400 (explaining that the penal process became "politicized" and the judiciary "became a convenient symbol for criminal justice system-related frustrations"); $c f$. Lanni, supra note 103, at 1782 (describing the similar effect of electoral pressures on politicians and legislators).

216. Lanni, supra note 103 , at 1780.

217. The appellate courts must determine whether the sentence is reasonable by applying sentencing factors enumerated by Congress. United States v. Booker, 543 U.S. 220, 261 (2005).

218. See Adelman \& Dietrich, supra note 215 (discussing the importance of habeas review of state court convictions). 
judges through repeated exposure to mitigation and serves as another compelling reason for defense lawyers to expand and routinize the presentation of life history mitigation in noncapital sentencing proceedings.

Another way in which death is different is that capital cases are bifurcated, and sentencing is a stage of trial over which the jury presides and at which the prosecution and the defense generally present live witnesses. Structurally, it is more formal and anticipates a good deal more evidence than is usually involved in noncapital judge sentencing, though contemporary noncapital sentencing more often than not does involve advocacy from both sides. ${ }^{219}$

In addition, a capital sentence can never be mandatory, ${ }^{220}$ while in noncapital sentencing-beginning in the late 1970s in response to criticisms about discretionary sentencing leading to inconsistent, racially biased punishment ${ }^{221}$ - both federal and state criminal statutes moved toward uniform determinate and mandatory sentencing, with an explicit departure from individualization. ${ }^{222}$ Strong arguments pointing to wide sentencing disparities in pre-Guidelines systems support uniformity, treating like cases alike, and reducing the risk of individual sentencing bias-particularly racial bias. These arguments favor determinate, offense-based punishment and suggest that a return to individualization runs the risk of a return to inconsistency in punishment, where the least advantaged are the most likely to face the harshest penalties. One response to this argument is that the preGuidelines era of individualized punishment mostly pre-dated the developments in capital mitigation, described supra Part III, that form the basis of the recommendation that noncapital mitigation follow a similar trajectory. In other words, we do not actually know what noncapital individualization - a type based on meaningful mitigation investigation aimed at identifying human frailty and explaining law-breaking behaviorlooks like or how it works because that practice has not taken hold on a wide scale outside capital cases.

In any event, determinate and mandatory punishment regimes introduced a seismic shift in criminal sentencing that eschewed

219. See Hessick, supra note 26 , at 1080 (discussing the changing role of counsel at the sentencing phase).

220. See Roberts v. Louisiana, 428 U.S. 325,336 (1976) (holding Louisiana's mandatory death sentence statute unconstitutional); Woodson v. North Carolina, 428 U.S. 280, 305 (1976) (holding North Carolina's mandatory death sentence statute unconstitutional).

221. Dharmapala et al., supra note 23, at 1040, 1044.

222. See Haney, War on Prisoners, supra note 23, at 377-86 (discussing the emergence of determinate sentencing and abandonment of rehabilitative, individualized sentencing); Dharmapala et al., supra note 23, at 1043-44. Uniformity was also paramount to the Furman decision striking down capital punishment as being inconsistently imposed. Furman v. Georgia, 408 U.S. 238, 309 (1972). Furman then gave way to Gregg's "guided discretion," which relies on juries' consideration of individualized mitigating and aggravating factors. Gregg v. Georgia, 428 U.S. 153, 206 (1976). Meanwhile, uniformity in noncapital sentencing remains robust, likely because of legislatures' perception that judges, as professional repeat actors, can more easily be relied on to impose uniform sentences. 
rehabilitation in favor of offense-centered, "just deserts" punishments that have dramatically increased the number and length of prison sentences courts have imposed in the last four decades. ${ }^{223}$ In fact, the Supreme Court has upheld the application of mandatory noncapital sentences, even for life without the possibility of parole. ${ }^{224}$ At the same time, the only context in which the Supreme Court has held that a noncapital defense lawyer's sentencing failure has resulted in prejudice, thus violating the Sixth Amendment right to the effective assistance of counsel, has been that of a mandatory sentence resulting in a significantly harsher penalty than would have resulted absent counsel's calculation error. ${ }^{225}$ In the years since that case was decided, the Supreme Court has curtailed mandatory sentencing, in cases such as United States v. Booker, and has required prosecution teams to prove beyond a reasonable doubt the presence of any sentencing factor besides a prior conviction that can increase a sentence beyond the statutory maximum. ${ }^{226}$ Additionally, as described supra Part III.C., Miller/Jackson provides another opening for a return to individualized sentencing. ${ }^{227}$

Despite these decisions pushing back against mandatory determinate sentencing, absent consideration of individual offenders' characteristics, uniformity and just deserts remain the dominant punishment paradigm within which noncapital mitigation practice operates for the time being. 228 One might argue that - particularly because uniform sentencing schemes are almost exclusively offense-centered ${ }^{229}$-determinate sentencing is an obstacle to the investigation and presentation of social history mitigation since judges must impose a sentence within a particular range, often with mandatory minimums ${ }^{230}$ in the federal system as well as in many states, ${ }^{231}$ upon conviction of certain crimes. ${ }^{232}$ In fact, the opposite is true. In mandatory sentencing regimes, it is all the more imperative that

223. Haney, War on Prisoners, supra note 23, at 391.

224. Harmelin v. Michigan, 501 U.S. 956, 996 (1991).

225. See Hessick, supra note 26, at 1081-82 (discussing Glover v. United States, 531 U.S. 198, 203-04 (2001)).

226. See Hessick, supra note 26 , at $1082-85$ (discussing Blakely v. Washington, 542 U.S. 296, 303 (2004); United States v. Booker, 543 U.S. 220, 245 (2003); and Apprendi v. New Jersey, 530 U.S. $466,490-92(2000))$.

227. See supra note 79 and accompanying text.

228. Haney, War on Prisoners, supra note 23, at 410.

229. Id. at 394 .

230. See, e.g., Kimbrough v. United States, 552 U.S. 85, 93, 105 (2007) (noting the lower court's disapproval of the disproportionate limitations on sentencing under the Guidelines and discussing in detail the disproportionality between Guidelines sentences for trafficking crack cocaine and for trafficking powder cocaine).

231. See, e.g., Tonry, supra note 35 , at 69 .

232. See Lanni, supra note 103, at 1783, 1785 ("[T] The Federal [Sentencing] Guidelines severely curtail judicial discretion by declaring 'not ordinarily relevant' many personal characteristics of the offender previously considered by sentencing judges, such as . . . mental and emotional conditions, socioeconomic status, and 'lack of guidance as a youth and similar circumstances indicating a

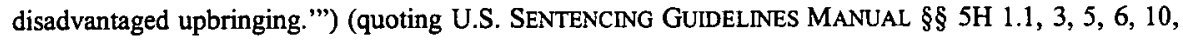
12 (1998)). 
defense lawyers present whatever credible evidence is available to persuade prosecutors to adjust their charging decisions to avoid conviction for offenses involving lengthy mandatory sentences. ${ }^{233}$ Defense attorneys must also present courts with persuasive reasons to either depart from the Sentencing Guidelines or sentence their clients to the lower end of the mandatory range.

Rita $v$. United States is an example of both the availability and the limits of an individualized sentencing presentation within a Guidelinesreliant system. ${ }^{234}$ Rita, a U.S. military veteran who had served as a cooperating law enforcement witness in other cases, faced sentencing for making false statements to a federal grand jury. ${ }^{235}$ The probation department, with the help of the defense and the prosecution, produced a presentence report that considered both "the offenses and... the offender," ${ }^{236}$ including "Rita's personal and family data, Rita's physical condition (including a detailed description of ailments), Rita's mental and emotional health," as well as his educational background and his twentyfive years of military service. ${ }^{237}$ The presentence report cited no circumstances that warranted departure from the Sentencing Guidelines. ${ }^{238}$ Rita's lawyer agreed with the judge's identification at sentencing of two factors warranting departure from the Guidelines: Rita's cooperation with law enforcement, which made him a "vulnerable defendant" in prison, and his military service. ${ }^{239}$ Defense counsel presented Rita's "poor physical condition" as a third reason and argued that "[j]ust [those] three special circumstances" warranted a below-Guidelines sentence. ${ }^{240}$ The court was not persuaded and sentenced Rita to thirty-three months in prison, the bottom of the Guidelines range. ${ }^{241}$ As Justice Stevens suggested in his concurrence, however, even though aspects of Rita's personal history were introduced at his sentencing, the Guidelines did not allow for their meaningful consideration. ${ }^{242}$ In particular, the Guidelines did not account for the "significant recognition" Rita received for his military service, and neither did the sentencing court. ${ }^{243}$ Rita illustrates the mechanical, actuarial

233. See Lanni, supra note 103 , at 1786 ("[D]eterminate sentencing merely shifts power and discretion from the sentencing judge to prosecutors and probation officers ...."); Richman, supra note 192, at 1386 ("With substantial control over the flow of offense-related facts to the judge, and even over the investment of resources in the discovery of facts to begin with, prosecutors were left with unprecedented sway over sentencing.").

234. 551 U.S. 338,338 (2007) (holding that a federal court of appeals may apply a presumption of reasonableness to a district court sentence that is within the properly calculated Federal Sentencing Guidelines range).

235. Id. at 341,345 .

236. Id. at 342 .

237. Id. at 343-44.

238. Id. at 344 .

239. Id. at $344-45$.

240. Id. at 345 (alteration in original).

241. Id.

242. Id. at 367 .

243. Id. 
approach to "individualized" sentencing presentations under a Guidelinesbased regime. ${ }^{244}$ Rita's lawyer presented "just those three" special circumstances. The Court made no mention of any comprehensive social history or narrative describing who Rita was or any convincing presentation of what pressures, incentives, or medical conditions may have influenced his behavior. The sentencing court was apparently expected to look at three discrete categories of mitigating information and decide, simply because they could be checked off a list, that Rita deserved a lower sentence. Such a sentencing presentation in a capital case would fall short of accepted defense standards where, at minimum, "connecting the dots" of mitigating factors and explaining their impact on the defendant's behavior is basic and critical to a persuasive sentencing. ${ }^{245}$ In fact, capital mitigation is almost universally aimed at showing how a defendant's multi-dimensional life does not conform to a grid of the sort that Guidelines-based sentences depend on.

Rita shows that, even post-Booker, the Sentencing Guidelines cast a long shadow over federal sentencing and remain a hurdle to a truly comprehensive consideration of social history mitigation. Rita further demonstrates that defense lawyers whose practice continues to be limited by the strictures of the "relevant" Guidelines considerations will fail to do their clients justice. ${ }^{246}$

In many ways, mandatory regimes present the same binary question that capital proceedings do: Has the defendant's conduct fallen in the range requiring application of particular sentencing reductions or enhancements? ${ }^{247}$ This determination requires prevailing on the decisionmaker's sense that the particular defendant standing before her is less blameworthy than another convicted of the same offense. At its base, all sentencing is subjective and defense lawyers must routinely investigate their clients' life histories and determine which factors are most likely to inspire mercy. This paper calls for a move away from the crime-focused, decontextualized, heavily retributive sentences that determinate schemes require, ${ }^{248}$ and a move toward a more rehabilitative, individualized approach to punishment that depends on meaningful consideration of mitigating circumstances. Over time, the persistent presentation of

244. Cf. Gall v. United States, 552 U.S. 38, 58 (2007). Gall describes a district court's departure from the Guidelines and imposition of probation following a conviction for conspiracy to distribute 10,000 ecstasy pills following the presentation of a substantial amount of evidence of Gall's immaturity at the time of the offense and subsequent rehabilitation and years of legitimate employment. Id. at 4143.

245. Dennis N. Balske, New Strategies for the Defense of Capital Cases, 13 AKRON L. REV. 331, 357-58 (1979), cited with approval in Russell Stetler \& W. Bradley Wendel, The ABA Guidelines and the Norms of Capital Defense Representation, 41 HOFSTRA L. REV. 635, $672 \mathrm{n} .189$ (2013).

246. See generally Rita, 551 U.S. at 347 (discussing a presumption of reasonableness when the trial court follows the Sentencing Guidelines range).

247. Hessick, supra note 26, at 1089.

248. See Lanni, supra note 103 , at 1787 (noting recent academic critique of determinate sentencing and the need for an individualized approach to sentencing). 
noncapital mitigation may erode support for mandatory sentencing altogether as defense lawyers, prosecutors, and courts realize that individual life circumstances and characteristics matter and there is no one-size-fits-all approach to punishment. ${ }^{249}$

With regard to non-mandatory sentencing, Professor Carissa Byrne Hessick has urged further development of noncapital professional norms and substantive case law governing discretionary noncapital sentencing. ${ }^{250}$ Professor Hessick has argued that, in many ways, noncapital discretionary sentencing is not unlike capital sentencing; and, therefore, Sixth Amendment claims challenging the sentencing performance of defense counsel should only have to prove a reasonable probability that the defendant's sentence was increased by any amount of actual jail time. ${ }^{251}$ However, the relatively broad standards for the type of mitigation defense lawyers need to investigate in noncapital cases presents a challenge in proving ineffective assistance during discretionary noncapital sentencing. ${ }^{252}$ Professor Hessick suggests that constitutionally required investigation of capital mitigation may provide a foundation for noncapital cases, ${ }^{253}$ but the "death is different" doctrine again proves to be a formidable hurdle here since there is no Sixth Amendment requirement that mitigation be presented in a noncapital case. As Professor Hessick recognizes, the baseline requirements of the types of mitigation that must be investigated have been far better developed in the capital context. ${ }^{254}$

The Supreme Court's longstanding Eighth Amendment jurisprudence, and the practical reality that death remains unique in its irreversibility and in its degree of cruelty, requires the conclusion that death is different (for the time being). Development of capital judicial decisions and defense practices is impossible to divorce from this context. There is almost no comparable noncapital case law and, as discussed previously, the noncapital sentencing professional standards, while providing an outline of basic duties, pale in comparison to the capital guidelines. ${ }^{255}$

In light of the comparatively general noncapital professional standards and a lack of substantive case law establishing a top-down constitutional duty to investigate and present noncapital mitigation, the most immediate avenue for improving noncapital defense sentencing baselines remains changing defense lawyers' actual standard of practice in everyday cases. This is the best hope for changing the expectations of courts (both in sentencing and habeas proceedings), prosecutors, and clients

249. See Barkow, supra note 19, at 1205 (advocating for uniform capital and noncapital sentencing standards in order to prohibit mandatory noncapital sentencing, which would "make a dramatic difference for thousands upon thousands of defendants serving [mandatory] sentences").

250. Hessick, supra note 26, at 1111-12,1121-22.

251. Id. at $1087,1090$.

252. Id. at $1106-07$.

253. Id. at $1107-09$.

254. Id. at 1107 .

255. Id. at 1110 . 
about what basic and competent noncapital sentencing advocacy requires, and for ensuring that noncapital sentencing courts moderate sentences and account not only for the facts of the offense, but also for the unique individual frailties of the offender. ${ }^{256}$

\section{Conclusion}

Individualized noncapital sentencing appears to be resurging and its expansion will have an impact on incarceration rates. The Supreme Court's recent emphasis that the background of a convicted person is as important as the crime itself should serve as a clarion call for institutional change. Though resource and doctrinal constraints present challenges to a full reconciliation of capital and noncapital mitigation practice, a good deal of change can begin immediately by reorienting defense lawyers to take mitigation as seriously in noncapital cases as capital defense lawyers do, and to realign their practices and professional standards accordingly.

Making mitigation central to noncapital sentencing will benefit individual defendants by reducing prison time and will simultaneously result in more systemic reform, which sheds light on root causes of crime by explaining factors that actually influence defendants' behavior before they break the law. Routine and robust noncapital mitigation presentations will also change sentencing courts' expectations of sentencing practice and increase the eventual likelihood of a new constitutional baseline for mandatory noncapital sentencing mitigation as there has been for decades in capital cases.

Finally, I will end on a grace note- - one played out in a noncapital case which, like scores of cases all over the country, is by most measures unremarkable to anyone but the defendant, who was spared prison, and her family. The court that sentenced the defendant allowed for hope and the possibility of a successful future because it paused to consider the range of circumstances that influenced her behavior. This case also speaks to the reality of many defendants' life courses, which often include relapses into criminal involvement rather than an undeviating line to immediate redemption.

In 2002, Chastity Hawkins, a young woman from the South Bronx with no prior criminal record, pled guilty to federal fraud charges stemming from participation in the "family business," 257 led by her father, which

256. See Steiker \& Steiker, Entrenchment, supra note 7 , at 239 (discussing the professionalization and improved practice of the capital defense bar as contributing to the greater scrutiny of capital sentences). Successful habeas challenges to defense sentencing failures can provide a wider-reaching doctrinal foundation for improved sentencing representation in noncapital cases as they have in capital cases, so it is also important to consider bringing these challenges in cases with strong facts. Yet another significant challenge to more robust noncapital habeas practice is the fact that noncapital prisoners, unlike death row prisoners, have no statutory right to counsel in federal habeas. See 18 U.S.C. $\$ 3599$ (a) (statute granting death row prisoners the right to counsel in federal habeas proceedings).

257. United States v. Hawkins, 380 F. Supp. 2d 143, 145 (E.D.N.Y. 2005), aff'd, 228 Fed. 
involved defrauding insurance companies by staging car accidents and then "initiating false legal and medical claims based on fabricated injuries."258 Hawkins' conviction exposed her to a $\$ 148,814$ restitution charge and a 12 to-18-month prison sentence under the Federal Sentencing Guidelines. ${ }^{259}$ Defense counsel moved for a downward departure on the grounds of extraordinary family circumstances and extraordinary rehabilitation, based in part on her being a young mother, though Hawkins herself admitted "she was not a great mother ...."260 During this initial proceeding, "the court . . . [nevertheless] had a strong impression that [Hawkins] . . . may have bottomed out, that is reached the end of her difficulties, and that she was coming back into useful society." ${ }^{261}$ Based on this assessment, the court granted a year-long supervised adjournment of sentencing so that Hawkins could have "a chance to show full rehabilitation."262 Yet within that year, she continued to commit fraud, this time by falsely certifying she was not working while simultaneously collecting unemployment checks. ${ }^{263}$ At the end of the probation, the court nevertheless took into account the progress Hawkins had made in legitimate employment as well as in her relationship with her daughter and determined that she had demonstrated "extraordinary rehabilitation"- a formal downward departure under the Sentencing Guidelines. The court sentenced her to three years of probation and full restitution. ${ }^{264}$

The case was remanded after the government's post-sentencing appeal challenging the conclusion that Hawkins had been rehabilitated. During remand, Hawkins' attorney submitted a motion for downward departure as well as for a non-Guidelines sentence, ${ }^{265}$ and the district court held a hearing on evidence of extraordinary rehabilitation. The hearing provided an unusually detailed record explaining a noncapital sentencing court's sentencing considerations. The defense motion argued extensively that Hawkins deserved a non-incarceration sentence because of her successful employment, attainment of a GED, and general stabilization of her life. ${ }^{266}$ The motion also described the importance of Hawkins' support of her nine-year-old daughter. ${ }^{267}$ It also referred to Hawkins' diminished relative culpability and "truly extraordinary" transformation " $[w]$ hen

\footnotetext{
Appx. 107 (2d Cir. 2007).

258. Id.

259. Id.

260. Id.

261. Id. at 162 .

262. Id. at 166

263. Id. at 169 .

264. Id. at 167 .

265. Motion for Downward Departure at 8-9, United States v. Hawkins, No. 1:02-CR-563-JBW (E.D.N.Y. 2005), ECF No. 358

266. Id. at 4-5.

267. Id. at 4, 6. Previously, Ms. Hawkins' daughter had been in court with her and had impressed the court with her straight-A report card. Transcript of Sentencing Record at 4, United States v. Hawkins, 380 F. Supp. 2d 143 (E.D.N.Y. 2005) (No. 02-CR-563).
} 
considered in the context of her past life and resources, or lack thereof." 268 During the evidentiary hearing, Hawkins testified that before her arrest, she was mainly receiving help from public assistance and her father when she was not working. She also reported that she partied every week, spent a lot of time shopping, and had not been a good mother. ${ }^{269}$ By contrast, Hawkins testified that after her arrest she developed a much better relationship with her daughter ${ }^{270}$ and that her marriage to her daughter's father (who remained incarcerated as he had been almost since the child's birth) had brought the family closer together. ${ }^{271}$ She also testified to an improved work ethic and to developing employment skills. 272 Hawkins also attested that she did not know who would care for her daughter if she were incarcerated. The government nevertheless argued in support of the 12-to18-month maximum prison sentence and cited, among other reasons, Hawkins' fraud during the pre-sentencing adjournment and Hawkins' lies to a probation officer about being fired from a job for impermissibly cashing checks. ${ }^{273}$

The court concluded at the end of the hearing that Hawkins had, despite occasional missteps, indeed exhibited extraordinary rehabilitation. This required a view of Hawkins' behavior in the context of her family and social history: "A rehabilitative design takes into account the fact that a person's actions may reflect genetics, social advantage, and deprivation as well as free will, merit, and culpability . . . . Pure retribution, or 'just deserts,' ignores the handicapping effect of social, economic, and natural deprivation."274 As to Hawkins' particular deprivations, the court considered her "dysfunctional" family history significant. ${ }^{275}$ Her crimes, after all, had been at the behest of her father, and both her parents were "career criminals" who had spearheaded the instant conspiracy. ${ }^{276}$ Her father was "an alcoholic ... who used his position of power in the

268. Motion for Downward Departure at 6-7, United States v. Hawkins, No. 102-CR-563-JBW (E.D.N.Y. 2005), ECF No. 358.

269. Hawkins, 380 F. Supp. 2d at 170-71.

270. Id. at 171 .

271. Id.

272. Id.

273. Government's Proposed Findings of Fact and Conclusions of Law, United States v. Hawkins, No. 102-CR-563-JBW (E.D.N.Y. 2005), ECF No. 369.

274. Hawkins, 380 F. Supp. 2d at 150-51. The court quoted Jonathan Kozol's Amazing Grace, a book about the extreme poverty blighting the communities in New York City from which nearly three quarters of New York state prisoners hail. Howkins, 380 F. Supp. 2d at 151 (citing JONATHAN KOZOL, AMAZING GRACE 3-5 (Perennial ed. 2000)). During a lengthy analysis of the Federal Sentencing Guidelines, the court rejected the government's rather perverse argument that someone with a relatively law-abiding life who engages in low-level criminal conduct cannot benefit from the extraordinary rehabilitation departure because her conduct was never so bad as to warrant any extraordinary rehabilitation. Hawkins, 380 F. Supp. 2d at 158-59.

275. Hawkins, 380 F. Supp. 2d at 172 . Ms. Hawkins' attorney had referred in the Motion for Downward Departure to her father's role in introducing her to fraudulent activity. Motion for Downward Departure, supra note 268, at 8.

276. Hawkins, 380 F. Supp. $2 \mathrm{~d}$ at 174. 
household to pressure other members into illegal conduct."277 The court gave great shrift to Hawkins' efforts to educate and train herself in skills that had allowed her to maintain legitimate, gainful employment. ${ }^{278}$ Finally, the court described the circumstances of Hawkins' dropping out of high school in eleventh grade:

[Hawkins was] attack[ed] by a twenty-five year old stranger who threw acid on her face ... [which] caused extensive facial scarring that is still visible in the form of welts across her face and neck. She was reluctant to be seen in public for a year following this attack, which was a contributing factor to her leaving school. ${ }^{279}$

It is not difficult to imagine this extraordinary interruption of opportunity alone inspiring the court's empathy. The court also took into great account Hawkins' evolving relationship with her daughter and that she had done "what was reasonably within her power to normalize her daughter's life." 280

In addressing Hawkins' missteps while her sentencing was pending, the court concluded, with empathy tempered by years of practical observation, that when defendants are "emerging from troubled or criminal circumstances, backsliding is not an uncommon occurrence." ${ }^{281}$ In the end, the court concluded that, after some setbacks, Hawkins was building a "law-abiding lifestyle"282 and that probation was the only viable sentence, as any term of incarceration would not account for Hawkins' rehabilitation and "would have a disastrous effect on [Hawkins'] daughter, a matter of importance in sentencing jurisprudence." 283

The unmistakable impact of social history mitigation was fully evident as the court considered the young woman's conduct and future prospects:

A child forced into crime by a criminal father surely emerges from a different starting point than the child of a legitimately employed parent .... Defendant's background reflected social as well as socioeconomic deprivation-a scarred personality as well as an acid-etched visage. That she has progressed from an irresponsible white collar criminal to a law-abiding hard working

277. Id. at 172 .

278. Id. at 164 .

279. Id. at 172-73. The Motion for Downward Departure had also mentioned the acid attack. Motion for Downward Departure, supra note 268, at 5. Ms. Hawkins had also testified about the attack and about its impact on her ability and willingness to go out in public, including the fact that she was hospitalized for three months because of her injuries. Hawkins, 380 F. Supp. 2d at 173.

280. Hawkins, 380 F. Supp. $2 \mathrm{~d}$ at 175.

281. Id. at 176.

282. Id. at $177-78$.

283. Id. at 178 . 
citizen is quite extraordinary, given this starting point. ${ }^{284}$

This is the grace note, the pursuit of which is certainly worthy for more outcomes like this. 